OPEN ACCESS

Edited by:

Giorgio Bavestrello,

University of Genoa, Italy

Reviewed by:

John Klinck,

Old Dominion University,

United States

Gregory Lane-Serff,

The University of Manchester,

United Kingdom

*Correspondence:

Ricardo Giesecke

ricardo.giesecke@uach.cl

Specialty section:

This article was submitted to

Coastal Ocean Processes,

a section of the journal

Frontiers in Marine Science

Received: 27 October 2020

Accepted: 19 August 2021

Published: 01 October 2021

Citation:

Giesecke R, Martín J, Piñones A,

Höfer J, Garcés-Vargas J,

Flores-Melo X, Alarcón E,

Durrieu de Madron X, Bourrin F and

González HE (2021) General

Hydrography of the Beagle Channel,

a Subantarctic Interoceanic Passage

at the Southern Tip of South America.

Front. Mar. Sci. 8:621822.

doi: 10.3389/fmars.2021.621822

\section{General Hydrography of the Beagle Channel, a Subantarctic Interoceanic Passage at the Southern Tip of South America}

\author{
Ricardo Giesecke ${ }^{1,2 *}$, Jacobo Martín ${ }^{3,4}$, Andrea Piñones $1,2,5$, Juan Höfer ${ }^{2,6,7}$, \\ Jose Garcés-Vargas 1,2, Ximena Flores-Melo ${ }^{3}$, Emilio Alarcón ${ }^{2,8}$, \\ Xavier Durrieu de Madron ${ }^{9}$, François Bourrin ${ }^{9}$ and Humberto E. González ${ }^{1,2}$ \\ ${ }^{1}$ Instituto de Ciencias Marinas y Limnológicas, Universidad Austral de Chile, Valdivia, Chile, ${ }^{2}$ Centro FONDAP \\ de Investigación en Dinámica de Ecosistemas Marinos de Altas Latitudes (IDEAL), Valdivia, Chile, ${ }^{3}$ Centro Austral \\ de Investigaciones Cientificas (CADIC-CONICET), Ushuaia, Argentina, ${ }^{4}$ Instituto de Ciencias Polares, Ambiente y Recursos \\ Naturales, Universidad Nacional de Tierra del Fuego (ICPA-UNTDF), Ushuaia, Argentina, ${ }^{5}$ Centro COPAS-Sur Austral, \\ Universidad de Concepción, Concepción, Chile, ${ }^{6}$ Escuela de Ciencias del Mar, Pontificia Universidad Católica de Valparaíso, \\ Valparaíso, Chile, ${ }^{7}$ Fundación San Ignacio de Huinay, Huinay, Chile, ${ }^{8}$ Centro de Investigación en Ecosistemas de la \\ Patagonia, Coyhaique, Chile, ${ }^{9}$ CEFREM, CNRS - Université de Perpignan Via Domitia, Perpignan, France
}

The Beagle Channel $(\mathrm{BC})$ is a long and narrow interoceanic passage $(\sim 270 \mathrm{~km}$ long and $1-12 \mathrm{~km}$ wide) with west-east orientation and complex bathymetry connecting the Pacific and Atlantic oceans at latitude $55^{\circ} \mathrm{S}$. This study is the first integrated assessment of the main oceanographic features of the $\mathrm{BC}$, using recent oceanographic observations from cruises, moored instruments and historical observations. The waters transported into the BC are supplied mainly by the Cape Horn Current, which carries Subantarctic Water (SAAW) at depth (100 m below surface) along the Pacific Patagonian continental shelf break. SAAW enters the continental shelf via a submarine canyon at the western entrance of the BC. The SAAW is diluted by fresh, nutrient depleted (nitrate, phosphate and silicic acid) Estuarine Water (EW) from Cordillera Darwin Ice Field (CDIF) forming modified SAAW (mSAAW). Freshwater inputs from the CDIF generate a two-layer system with a sharp pycnocline which delimits the vertical distribution of phytoplankton fluorescence (PF). Two shallow sills $(<70 \mathrm{~m}$ ) along the BC contribute to EW and mSAAW mixing and the homogenization of the entire water column east of the sills, coherent with Bernoulli aspiration. The central section of the BC, extending $\sim 100 \mathrm{~km}$ toward the east, is filled by a salty (31-32) variety of EW. In winter, this central section is nearly vertically homogeneous with low nutrient concentrations (0.9-1.1 $\mu \mathrm{M} \mathrm{PO4}$ and 7.5-10 $\mu \mathrm{M}$ NO3) and PF. The temporal variability of seawater temperature from 50 to $195 \mathrm{~m}$ in the central section of the $\mathrm{BC}$ was found to be mostly dominated by the annual and semiannual cycles and influenced by tidal forcing. The middle section of the $\mathrm{BC}$ was less influenced by oceanic inputs and its basin-like structure most likely favors retention, which was observed from the weakly stratified water column at the mooring site. Toward the east, the central section bathymetry is disrupted at Mackinlay Strait where another shallow 
sill separates the middle channel from the shallow eastern entrance that connects to the Atlantic Ocean. In this section, a weakly stratified two-layer system is formed when the eastward surface outflow (salty-EW) flows over a deeper, denser tongue of oceanic mSAAW.

Keywords: Beagle Channel, hydrography and bathymetry, micro-basins, interoceanic channel, southern Patagonia

\section{INTRODUCTION}

\section{Southern Patagonia Under a Climate Change Scenario}

The effects of climate change are expected to be more rapid and dramatic in high-latitude polar and subpolar environments (IPCC, 2014). Some of the most noticeable impacts are (a) the retreat of glaciers (due to melting and an increase in rainfall as compared to snowfall), and (b) the variation of atmospheric frontal systems and the resulting increase in extreme events, which ultimately modify both oceanic circulation and water properties, affecting the structure and function of marine ecosystems (Mackas et al., 2006).

The southern Patagonia icefields are among the last relics of the last glaciation. They comprise one of the largest fjord regions worldwide (Vargas et al., 2018), together with the fjord systems of Iceland, Scandinavia, Greenland, Alaska, and British Columbia. At the same time, they make up one of only two Subantarctic fjord regions, the other being the southern island of New Zealand. Situated at the southernmost extension of land before Antarctica, Tierra del Fuego and southern Patagonia constitute unique ecosystems and provide a natural laboratory for monitoring the effects of ongoing climate change.

The southern tip of the South America has a high geomorphological complexity, with fjords and protected embayments that are well-suited to the industrial production of aquatic marine organisms (e.g., salmon, blue mussels, and macroalgae), thanks to the calm and pristine waters, the high availability of phytoplankton (for blue mussels) and the temperature suitable for salmon farms. In the last decades, the salmon farm industry in particular has expanded toward the south in search of new areas to establish sites of aquaculture production. This move has been driven by the necessity to vacate the eutrophic waters generated by intensive aquaculture, with their inherent enhanced oxygen depletion and the various diseases engendered by the bad practices of the aquaculture industry during the last five decades (Buschmann et al., 2009; Pantoja et al., 2011). Aquaculture is now spreading toward the southern tip of South America, where still pristine environments are already facing the challenges of climate change; this increasing industrial pressure threatens these unique ecosystems, about which much has yet to be understood.

Studying this region is a challenge in its own right, due to the complex geomorphology and the difficulty to access most of the channels, which cover a vast surface area $\left(\sim 132,291 \mathrm{~km}^{2}\right)$. Furthermore, the region is subject to complex interactions between atmosphere, land, cryosphere, and ocean, and is under the strong influence of oceanographic features such as the Cape
Horn Current (CHC) (Strub, 1998; Strub et al., 2019). The $\mathrm{CHC}$ originates where the South Pacific Current from the west divides at around $40-45^{\circ} \mathrm{S}$, with the $\mathrm{CHC}$ going southward (Strub et al., 2019). The CHC is described as a surface current moving southward along the western shelf of Patagonia (Talley et al., 2011; Strub et al., 2013), transporting Subantarctic Water (SAAW) with a salinity in the range 33-34.2 and temperature between 7 and $9^{\circ} \mathrm{C}$ (Palma and Silva, 2004) along the coast. Close to the continent, the SAAW is diluted by fresh water from continental runoff, referred to as Estuarine Water (EW; salinity 1-32) which is subdivided in fresh-EW (salinity 1-11), brackish-EW (11-21) and salty-EW (21-31) (Silva et al., 1998; Valdenegro and Silva, 2003). As a result of the mixing of SAAW and EW, modified Subantarctic water (mSAAW) with a salinity in the range 3233 (Sievers et al., 2002) is formed. Due to complex bathymetry, there is a permanent input of SAAW into several fjords and channels, while others have limited or no exchange with SAAW, due to the presence of shallow sills which hinder its circulation (Palma and Silva, 2004). SAAW usually enters the fjords and channels of southern Patagonia between 50 and $75 \mathrm{~m}$ depth (Valdenegro and Silva, 2003; Sievers and Silva, 2006), filling a series of microbasins and modifying the physical and chemical properties (Valdenegro and Silva, 2003; Sievers and Silva, 2006; Brun et al., 2020). On the other hand, the freshwater inputs from rivers, coastal runoff, and the thawing of glaciers flow out at the surface, mixing with SAAW and transporting dissolved as well as particulate organic and inorganic matter into the channels and fjords (Valdenegro and Silva, 2003; Giesecke et al., 2019). This creates unique environments that shape ecosystem structure and functioning (Hamamé and Antezana, 1999; Palma and Silva, 2004).

Southern Patagonia faces strong westerlies throughout the year, with an intensification during the austral spring and summer (Garreaud et al., 2009), but these wind regimes are gradually being modified due to climate change. Records from the last four decades indicate that the prevailing zonal (eastwest) wind in the region has increased in intensity at a rate of $0.2-0.3 \mathrm{~m} \mathrm{~s}^{-1}$ per decade (Garreaud et al., 2013). Since 1990, there has been a significant increase in rainfall during the austral winter (June, $200 \mathrm{~mm}$ per decade) and a gradual decrease in spring and summer (González-Reyes et al., 2017). Atmospheric temperature is linked with the temporal variability of the Southern Annular Mode (SAM), generally defined as the mean sea level pressure difference between 40 and $65^{\circ} \mathrm{S}$. The SAM can shift between positive and negative phases associated with the North-South movement of the west wind belt and the path of frontal systems. Since 1940, a trend toward positive SAM phases has been predominant, favoring higher atmospheric 
temperatures associated with rising greenhouse gas emissions and increased ozone depletion (Abram et al., 2014).

\section{The Beagle Channel}

The Beagle Channel is the southernmost channel of the South American continent and one of the most prominent, due to the fact that it forms an uninterrupted conduit between the Pacific and the Atlantic oceans. This channel is a former tectonic valley that was completely covered by ice during the last glaciation (Bujalesky, 2011). The erosive action of glaciers and the subsequent deposits have shaped its present-day abrupt bathymetry, which includes semi-isolated basins (up to $400 \mathrm{~m}$ deep) and embayments separated by a series of shallow topographic sills (Bujalesky, 2011). The Channel has a Y-shape, with two arms at its Pacific end, hereafter named north-western and southern branches; these arms converge at $69^{\circ} \mathrm{W}$ to form a single channel (Figure 1b). North of the north-western branch, the CDIF supplies large inputs of freshwater (glacial meltwater) into the Beagle Channel via several fjords and rivers, while the southern branch receives melt and rainwater from surrounding continental runoff. At the eastern end of the north-western section, the main topographic sill is located at Diablo Island (close to Punta Divide, Figure 1e), where the Channel narrows from $2 \mathrm{~km}$ to $1 \mathrm{~km}$ and the sill rises to a depth $<50 \mathrm{~m}$. In the southern arm another shallow sill $(\sim 100 \mathrm{~m}$ depth $)$ is located at Fleuriais Bay (Figure 1d). The eastern section of the Beagle Channel basin (between Punta Divide and Gable Island) is separated from the Atlantic Ocean by shallow (30 m deep) and narrow topographic sills at Mackinlay Strait and Murray Channel, respectively (Figure 1f; Bujalesky, 2011). These topographic sills limit the circulation of water masses along the Channel (Valdenegro and Silva, 2003), leading to the formation of microbasins with distinct biotic and abiotic properties (Hamamé and Antezana, 1999; Diez et al., 2018).

The entire western section of the Beagle Channel is surrounded by the CDIF. Some of the glaciers of the CDIF are connected to the Channel through fjords located on either side of its north-western branch, while others flow directly into the main channel. In the southern branch of the Channel, glaciers are less numerous and are restricted to mountain tops. The eastern limit of the CDIF is located at Yendegaia Bay. Eastward from Yendegaia Bay, the number and extension of mountain glaciers tend to diminish, while dense river networks play a major role in supplying freshwater to the Channel. These freshwater discharges into the Channel are at present poorly constrained, while observations in the middle sector of the Channel show a clear seasonal pattern, with higher freshwater inputs during the spring/summer (October to January) (Iturraspe et al., 1989). The tidal regime is mixed semidiurnal with a tidal range of $2.3 \mathrm{~m}$ (D'Onofrio et al., 1989). It is generally agreed that the main circulation in the region is eastward, transporting waters of Pacific origin into the southwest Atlantic around Cape Horn and through the Strait of Magellan (Brun et al., 2020; Guihou et al., 2020 and references therein). Although the circulation is not well constrained in the particular case of the Beagle Channel, available observations and modeling efforts (e.g., Balestrini et al., 1990, 1998) also indicate an eastward net transport of surface waters flowing above the sills. Balestrini et al. (1990), for example, deployed near-surface current meters for periods of $48 \mathrm{~h}$ at 20 locations in the middle section of the Beagle Channel, and were able to describe current reversals associated with tides and residual currents. In all recording stations that were not influenced by very local bathymetric effects, the residual currents presented consistent eastward directions and current speeds between 2.6 and $13.7 \mathrm{~cm} \mathrm{~s}^{-1}$ (Balestrini et al., 1990). Comparable observations were obtained by Speroni et al. (2003) by means of a near-bottom current meter deployed in Mackinlay Strait.

More complex circulation patterns, including recirculating cells, have been observed in embayments such as Ushuaia Bay (Flores-Melo et al., 2020). Less is known about the deep circulation in sectors that are deep enough to host a two-layer system in which the mechanical action of winds, tides and waves is insufficient to mix the entire water column. In fact, both wind intensity and, in particular, wave height are significantly limited with respect to other locations of Southern Patagonia or the Drake Passage, owing to the sheltering effect provided by mountain ranges along the Beagle Channel.

The rapid growth of human settlements, maritime traffic, and industrial endeavors in the Channel call for the establishment of a baseline of the physical, chemical, and biological features of this ecosystem. Despite the relevance of the area, the Beagle Channel is at present understudied, and a complete description of the physical environment is lacking. Research in the Channel has been hindered by its remote location and also by the fact that the Channel is shared between Chile and Argentina, meaning that most research surveys have been conducted within the respective borders of each country. Indeed, coordinated efforts to study the entire Channel have been set up only recently.

This study aims to compile, for the first time, high resolution hydrographical data collected along the Chilean and Argentinian sections of the Beagle Channel in order to provide a detailed description of water mass properties at all depths throughout the Channel.

\section{MATERIALS AND METHODS}

\section{Along-Channel Hydrographic Transects}

Since October 2016, the IDEAL center (Research Center: Dynamics of High Latitude Marine Ecosystems) has conducted hydrographic transects yearly from the western end of the northwestern branch of the BC to Yendegaia Bay (Figures 1a-c). While during winter 2017 (July-August), simultaneous to the IDEAL transect, a full oceanographic survey onboard M/O Bernardo Houssay (PNA, Argentina) was conducted from nearby Yendegaia Bay to the eastern limit of the BC, thus generating for the first time a full, high resolution, hydrographic section along the entire Channel. The last survey was held during July 2018 along the northern and southern branch of the BC. In all the surveys, factory-calibrated CTDs (equipped with chlorophyll fluorescence and dissolved oxygen sensors), were used. The 


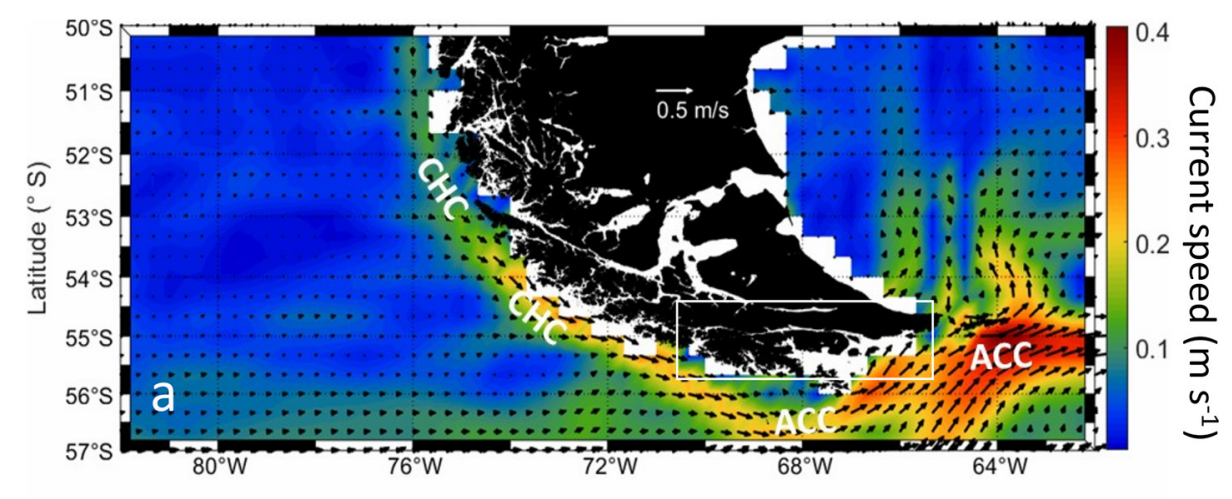

Longitude $\left({ }^{\circ} \mathrm{W}\right)$
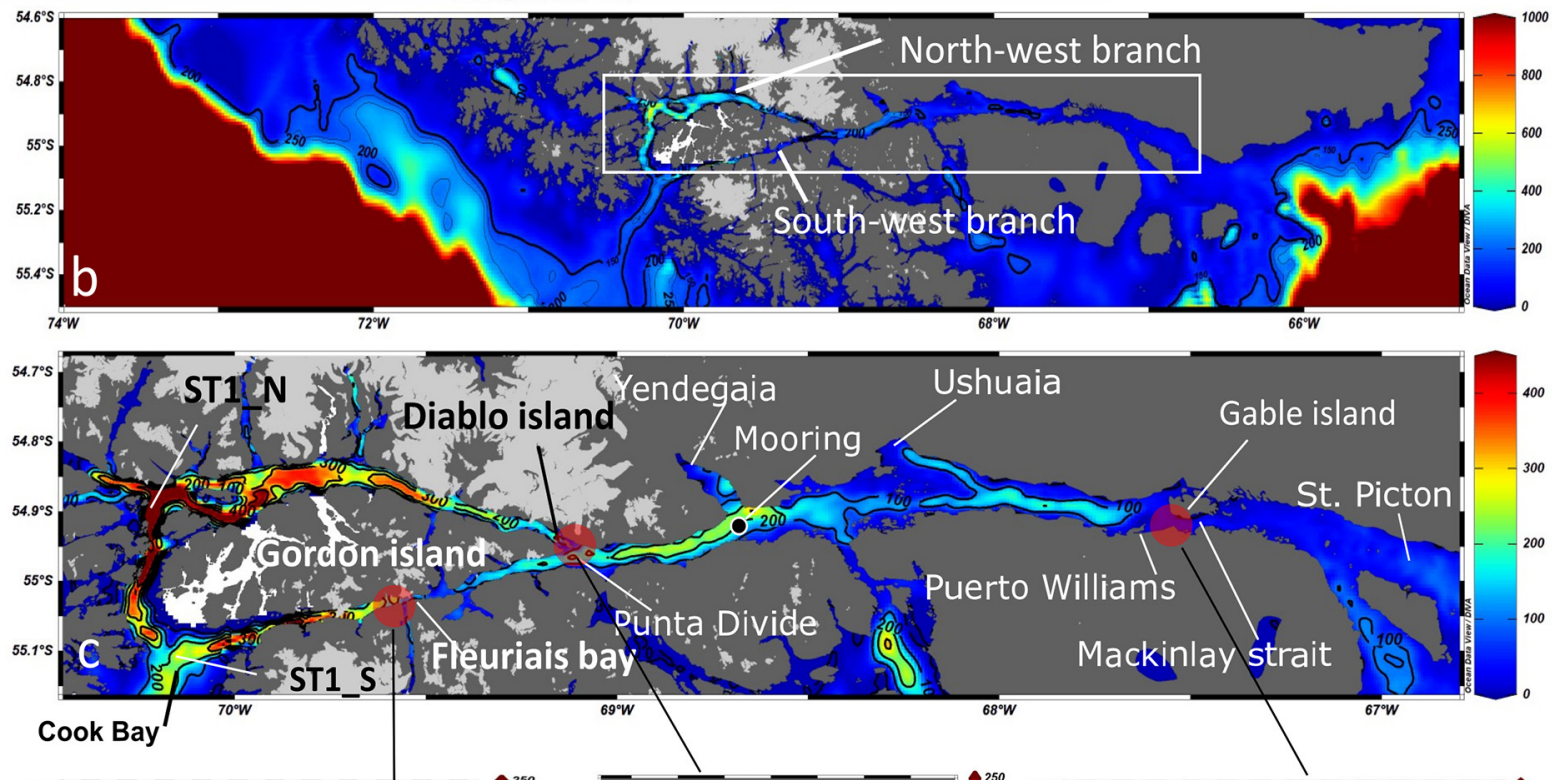

$68^{\circ} \mathrm{W}$

$66^{\circ} \mathrm{W}$

兽
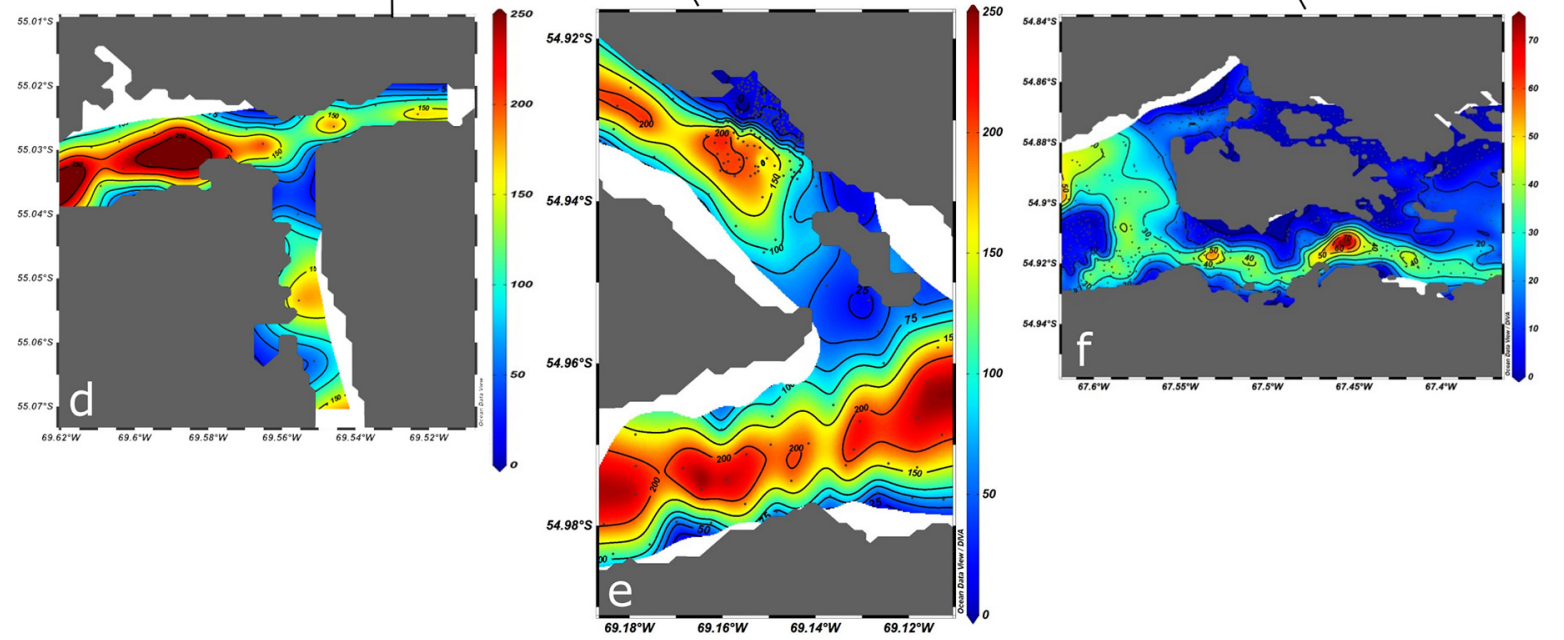

FIGURE 1 | (a) Map of the annual mean surface currents ( $\left.\mathrm{m} \mathrm{s}^{-1}, 1992-2019\right)$ at the southern tip of South America. Currents derived from the Ocean Surface Current Analysis Project (Bonjean and Lagerloef, 2002). The names of the main currents are indicated in white letters: ACC = Antarctic Circumpolar Current and $\mathrm{CHC}=$ Cape Horn Current. (b) Map of the study area bathymetry, including the $200 \mathrm{~m}$ isobath, highlighting canyon entrances and the NW and SW branches of the Beagle Channel. (c) Detailed bathymetry along the Beagle Channel including the principal toponymy. Light gray areas indicate the location of the Cordillera Darwin Ice Field, while white areas at the western section of Gordon Island denote a lack of bathymetric data. Detailed bathymetry of the main topographic sills along the Beagle Channel at (d) Fleuriais Bay, (e) Diablo Island, (f) Mackinlay Strait. Bathymetric charts of the Chilean Beagle Channel were provided by the Chilean Navy (SHOA), while bathymetry from the Argentinian sector was digitized from chart $\mathrm{H}-477$ (Argentinian Naval Hydrographic Service, SHN). The bathymetry of the continental shelf and slope was obtained from the General Bathymetric Chart of the Oceans (IOC et al., 2003). 
details are given in Table 1. The raw data from the CTDs were processed individually cast by cast, according to the protocol recommended by SBE and averaged to a vertical resolution of $0.5 \mathrm{~m}$. Data visualization and further analysis were performed using the Ocean Data View software (Schlitzer, 2020).

\section{Water Chemistry Along the Beagle Channel From Historical CIMAR-FJORD Campaigns}

Similar spatial coverage of the Beagle Channel but at lower spatial resolution was obtained through two research cruises sponsored by the Chilean Navy CIMAR 3 (1998) and CIMAR 16 (2010) (see Table 1). During both cruises, a rosette equipped with 24 Niskin bottles collected water samples at discrete depths for the analysis of macronutrients (nitrate $\left(\mathrm{NO}_{3}{ }^{-}\right)$, phosphate $\left(\mathrm{PO}_{4}{ }^{-3}\right.$ ) and silicic acid $\left(\mathrm{Si}(\mathrm{OH})_{4}\right)$. Water samples $(50 \mathrm{~mL})$ were fixed with mercury chloride, stored at $-20^{\circ} \mathrm{C}$ in acid-cleaned highdensity polyethylene bottles and analyzed as described by Atlas et al. (1971) (for more details see Valdenegro and Silva, 2003). These data were provided by the Chilean National Oceanographic and Hydrographic Data Center (CENDHOC).

\section{Time Series From an Oceanographic Mooring and Atmospheric Conditions}

An instrumented mooring was deployed from 21 July 2017 through 28 September 2019 in the middle section of the Beagle Channel ( $54^{\circ} 55^{\prime} 3.83^{\prime \prime} \mathrm{S}$; $68^{\circ} 38^{\prime} 48.72^{\prime \prime} \mathrm{W}$, see Figure 1c) and over a water depth of $280 \mathrm{~m}$. Temperature and conductivity loggers (Star Oddi) with a recording interval of $1 \mathrm{~h}$ were deployed at 50, 100, and $195 \mathrm{~m}$ depth. The latter was also equipped with a pressure sensor to confirm the final depth of each sensor after deployment. Due to the remoteness of the mooring site, the turnaround took place once a year. Prior to deployment and after recovery, a CTD (SeaBird 25plus) profile was conducted at the mooring site to calibrate the sensors and adjust for any potential drift during their deployment. Conductivity sensors underwent a considerable drift due to fouling and were ultimately discarded from further analysis.

Hourly temperature records at $50 \mathrm{~m}$ and $195 \mathrm{~m}$ were registered and analyzed for the period July 22, 2017 to September 27, 2019, while temperature at $100 \mathrm{~m}$ was recorded from July 22, 2017 to July 19, 2018 only.

Wind and atmospheric temperature data were obtained from the fifth major global European Centre for MediumRange Weather Forecasts (ECMWF) global reanalysis (ERA5) (Hersbach et al., 2020). The data have a horizontal resolution of $0.25 \times 0.25$ degrees. A grid of data points around the Beagle Channel was selected and analyzed. The grid point closest to the location of the mooring was selected to be analyzed in the temporal domain using time series analyses (Emery and Thomson, 1998). The ERA5 reanalysis, satellite wind products and in situ weather stations had previously been used to determine the spatiotemporal variability of the surface winds along Southern Patagonia (Pérez-Santos et al., 2019): the study validated surface wind reanalysis to surface in situ and satellite observations, and obtained satisfactory correlation coefficients (0.5 - 0.9) and RMSE between 2 and $4 \mathrm{~m} \mathrm{~s}^{-1}$. With this in mind, and considering that the study region is characterized by rugged topography that can shape and shift surface winds, caution must be employed when using the global scaled wind products provided by ERA5 to interpret the role of surface winds at smaller spatial scales: for this reason, we limit and focus the use of surface winds to determine main modes of temporal variability only.

To determine the principal modes of temporal variability in ocean and atmospheric conditions, hourly time series of ocean and atmospheric temperatures and winds were fit with annual and semi-annual harmonics. A residual was obtained by removing the annual and semi-annual cycles, the mean, and the trend. Afterward, spectra were calculated on the residual hourly time series by using fast Fourier transform.

TABLE 1 | Summary of each sampling campaign along the Beagle Channel (BC) included in this study, as well as and the instrumental mooring deployed at the central section of the $\mathrm{BC}$.

\begin{tabular}{|c|c|c|c|c|c|}
\hline Survey & Date & Spatial range & CTD model & $\begin{array}{c}\text { Biogeochemistry } \\
\text { analyses }\end{array}$ & $\begin{array}{c}\text { CTD } \\
\text { casts/sampling } \\
\text { stations }\end{array}$ \\
\hline CIMAR-3 & October 1998 & full BC & - & yes & 7 \\
\hline CIMAR-16 & Oct-Nov 2010 & full $B C$ & - & yes & 7 \\
\hline IDEAL-2016 & October 2016 & NW branch to Yendegaia & SBE 19plus & no & 16 \\
\hline IDEAL-2017 & July 2017 & NW branch to Yendegaia & Seabird 25plus & no & 11 \\
\hline Houssay-17 & August 2017 & Yendegaia to eastern limit of BC & Seabird 911plus & no & 39 \\
\hline IDEAL-2018 & July 2018 & NW branch to Yendegaia & Seabird 25plus & no & 13 \\
\hline IDEAL-2018 & July 2018 & Southern branch & Seabird 25plus & no & 6 \\
\hline Survey & Date & Spatial range & Sensors & $\begin{array}{c}\text { Biogeochemistry } \\
\text { analyses }\end{array}$ & Depths (m) \\
\hline Mooring Beagle & 21 Jul. 2017 to 28 Sept. 2019 & Mid-section Beagle Channel & Star-Oddi (Temperature) & no & 50,195 \\
\hline Mooring Beagle & 21 Jul. 2017 to 19 Jul. 2018 & Mid-section Beagle Channel & Star-Oddi (Temperature) & no & 100 \\
\hline
\end{tabular}


Subtidal variability in temperature and atmospheric conditions was also analyzed by calculating daily averages of time series and estimating the spectra for all variables. Cross-correlations (Emery and Thomson, 1998) were used to determine relationships between wind and ocean temperature at subtidal temporal scales. Cross-correlations were estimated between the daily averaged along-channel wind components, wind magnitude and ocean temperature at $50 \mathrm{~m}$ and $195 \mathrm{~m}$. A significance level of $95 \%$ was used.

\section{RESULTS}

\section{Bathymetric and Hydrographic Features Along the Beagle Channel}

The continental slope outside of the western section of the Beagle Channel is a relatively narrow $(53 \mathrm{~km})$ and steep margin. It is intersected by a submarine canyon which is $4 \mathrm{~km}$ wide and $250 \mathrm{~m}$ deep, on a continental shelf less than $100 \mathrm{~m}$ deep (Figure 1b). This canyon connects the two western branches of the Beagle Channel. The entrance of the NW branch presents a bathymetric depression which reaches a depth of $674 \mathrm{~m}$ and is the deepest part of the study area. The entrance of the SW branch, on the other hand, is on average shallower, reaching a maximum depth of $400 \mathrm{~m}$. The seafloor in both branches gradually ascends eastward over an uneven bathymetry. This deep section extends across $70 \mathrm{~km}$ along the NW branch and $40 \mathrm{~km}$ along the SW branch, ending with narrow $(1 \mathrm{~km})$ and shallow topographic sills at Diablo Island $(\sim 50 \mathrm{~m})$ and Fleuriais Bay $(\sim 100 \mathrm{~m})$ in the NW and SW branch, respectively (Figures 1d,e). The seafloor deepens abruptly eastward from each sill, reaching a maximum depth of $\sim 250 \mathrm{~m}$. Both channels converge in the Punta Divide, forming a microbasin which ends in the east at Ushuaia Bay. The depth profile of the eastern section off Ushuaia Bay decreases significantly, forming a narrow valley with depths of $\sim 150 \mathrm{~m}$ along the center of the Beagle Channel. In comparison, the borders of the Channel have a relatively shallow bottom depth $(<100 \mathrm{~m})$. Toward the east, there is another shallow ( $<30 \mathrm{~m}$ depth) and narrow (1.5 km wide) sill at Mackinlay Strait. East of this sill, the depth of the Channel is relatively shallow $(<40 \mathrm{~m})$, until reaching a transitory depression around $120 \mathrm{~m}$ deep in Picton Strait. Eastward from Picton Island, the Channel opens onto a broad and shallow continental shelf (depth $<75 \mathrm{~m}$ ) that ends rather abruptly at approximately $66.2^{\circ} \mathrm{W}$, where it reaches the continental slope.

At depth in the western section of the Beagle Channel, we observed relatively warm $\left(8-9^{\circ} \mathrm{C}\right.$; Figures $\left.2,3 \mathrm{~B}\right)$, saline $(>33$; Figures 3A, 4A-C), and less oxygenated (6.6-6.8 $\mathrm{mL} \mathrm{L}^{-1}$; Figures 3C, 5A-C) SAAW across several kilometers inside both channels. This water mass enters the north-western and southern branches of the Beagle Channel through deep canyons following the $25.5 \mathrm{~kg} \mathrm{~m}^{-3}$ isopycnal. This water mass flows along the NW and SW branches below $100 \mathrm{~m}$ depth until it reaches the sills in both branches, where its eastward movement is prevented (Figures 6A-D). At the surface in the western section of both branches, the input of diluted (salinity $<30$ ), cold (5$\left.6^{\circ} \mathrm{C}\right)$ and more oxygenated $\left(7-7.4 \mathrm{~mL} \mathrm{~L}^{-1}\right)$ water from the Cordillera Darwin Ice Field (CDIF) combined with continental runoff, forms surficial Estuarine Water (fresh-EW), which then mixes with the SAAW at depth, forming the mSAAW between 50 and $100 \mathrm{~m}$ (Figure 7). Over both sills (at Diablo Island and Fleuriais Bay) and to the east of them an isopycnal rise $\left(\sigma_{\theta}=24.75 \mathrm{~kg} \mathrm{~m}^{-3}\right)$ was seen to occur during every cruise (Figures 4A, 6A).

The vertical structure was slightly different according to the years and months sampled along the NW branch. During October 2016 (onset of austral spring), the SAAW in the NW branch was slightly colder, and estuarine water (fresh-EW sensu Valdenegro and Silva (2003) was slightly warmer and less oxygenated at the surface. During July 2017 and July 2018, the temperature of the SAAW increased by $0.5^{\circ} \mathrm{C}$, while surface fresh-EW remained almost the same (Figures 2A-C), albeit slightly more oxygenated than during 2016 (Figures 5A-C). Oxygen concentration in the upper $50 \mathrm{~m}$ of the water column is closely coupled with both Chl-a fluorescence along the entire transect (Figures 3A-C), and with the vertical structure of the water column. Chl-a fluorescence values were highest in the western part of the Channel during 2017 and 2018 (west of the Diablo Island sill), where the vertical structure of the water column was clearly defined by the upper fresh-EW and the lower SAAW, both separated by a pycnocline $\left(\sigma_{\theta}=24.75 \mathrm{~kg} \mathrm{~m}^{-3}\right)$ which further limited the vertical distribution of phytoplankton fluorescence (Figures 3A-C).

East of the $\sim 50$ and $\sim 100$-m deep sills in both western branches, mixing disrupts the pycnocline and the water column showed vertical mixing from surface to bottom (down to $250 \mathrm{~m}$ ). This homogenization results in higher dissolved oxygen concentrations and lower Chl-a fluorescence when considering the entire water column. During 2017, the section east of Yendegaia Bay was sampled, allowing us to follow the hydrography along the entire Beagle Channel. Toward the east of the Channel as the seafloor gradually rises, water temperature decreased slightly $\left(0.5^{\circ} \mathrm{C}\right)$, while salinity remained relatively constant through the entire water column. Along the middle section of the Channel between these two sills (at Diablo Island and Fleuriais Bay) and the Mackinlay sill, the main water mass filling the entire basin is consistent with salty-EW (sensu Sievers et al., 2002; Palma and Silva, 2004), as defined by a salinity 31-32 (Figure 7) with a potential density of $24.5-25.25 \mathrm{~kg}$ $\mathrm{m}^{-3}$, and temperature ranging between 5.25 and $7.2^{\circ} \mathrm{C}$. The most noticeable feature of this section was the increase in Chla fluorescence along the eastern section (Figure 3B), where bottom depth becomes shallower, coinciding with an increase in dissolved oxygen at the surface (Figure 5B). East of the sill at Mackinlay Strait (eastern section of the Beagle Channel), we observed more saline, oxygenated and slightly warmer waters, consistent with mSAAW, which enter beneath the less saline and colder waters that flow out of the Beagle Channel, thus creating a shallow pycnocline that follows the $25.5 \mathrm{~kg} \mathrm{~m}^{-3}$ isopycnal at $20 \mathrm{~m}$ depth (Figure 4B). 

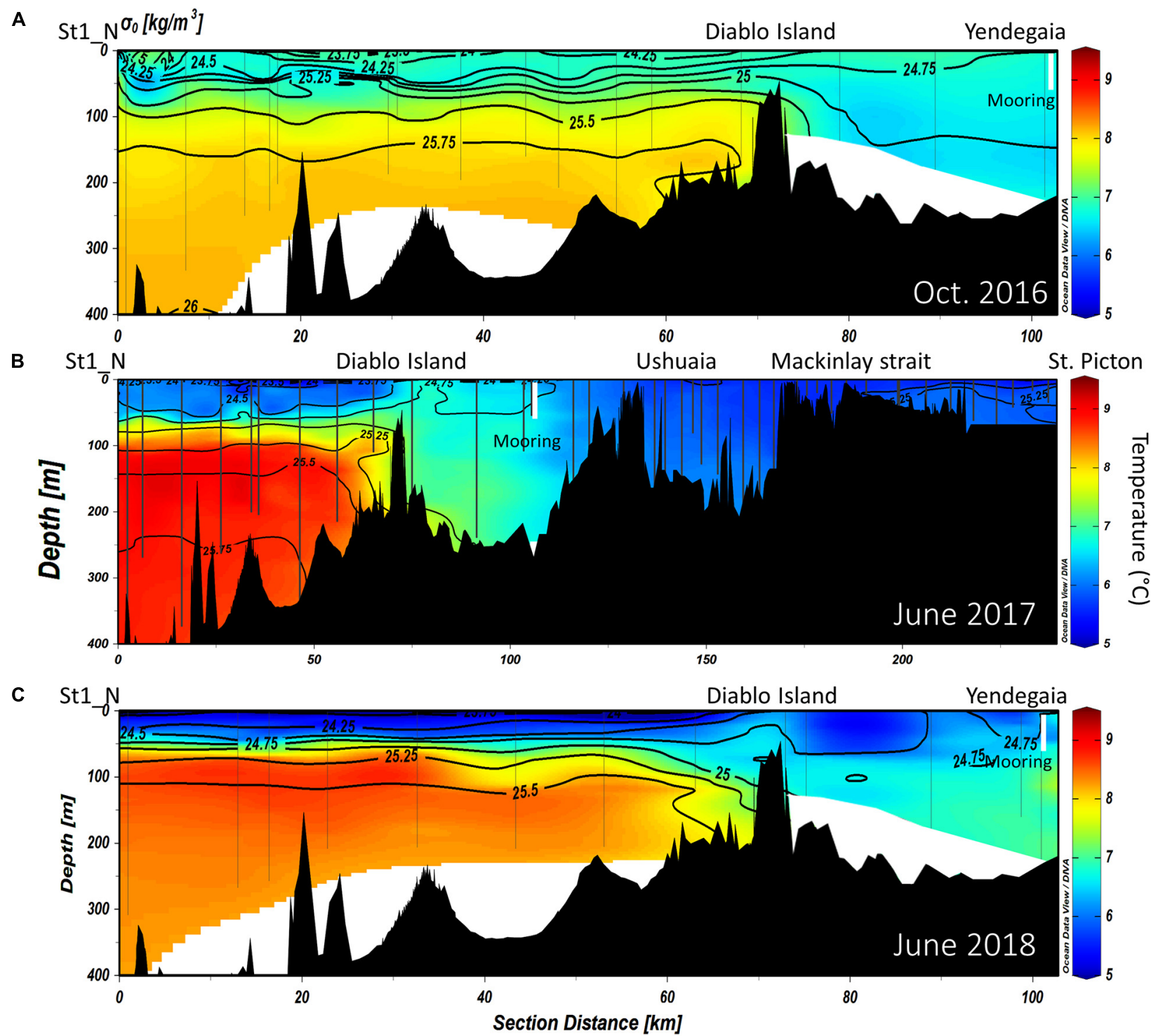

FIGURE 2 | Vertical distribution of potential temperature $\left({ }^{\circ} \mathrm{C}\right)$ overlaid by isopycnals of potential density along the NW branch of the Beagle Channel, during the (A) October 2016, (B) June 2017 and (C) June 2018 campaigns. Interpolated contours are created from individual CTD profiles (positions shown as vertical lines), where St1_N (left side of the figure) represents the westernmost station, and Yendegaia station the eastern part, sampled during 2016 and 2018 . During 2017 (B) the westernmost station extends from St1_N to St. Picton at the eastern end of the Beagle Channel. The position of the instrumented mooring is indicated by a vertical white line.

\section{Nutrient Distribution (CIMAR 3 and CIMAR 16 Cruises)}

During the CIMAR 3 (Oct-1998) cruise (Figures 8A-C), the highest concentrations of macronutrients (silicic acid, nitrate and phosphate) were found at depth, related to the inflow of SAAW at the northwestern entrance of the Beagle Channel, while the lowest values were observed at the surface where the high input of meltwater from the CDIF is transported from the fjords into the Channel, forming the fresh-EW and brackishEW. Nitrate and phosphate (Figures 8A,B) followed the same pattern as that observed for the physical properties along the Channel, with higher concentrations associated with the inflow of SAAW at the NW section of the Beagle Channel, west of the Diablo Island sill (Figures 8A-C). Phosphate (Figure 8A) and nitrate (Figure 8B) concentrations were highest at depth (>100 m depth) (1.3-1.6 $\mu \mathrm{M} \mathrm{PO}_{4}$ and 12.5-17.5 $\left.\mu \mathrm{M} \mathrm{NO} \mathrm{NO}_{3}\right)$ where SAAW was observed, while silicic acid (Figure 8C) showed a more heterogeneous distribution with few maxima at $200 \mathrm{~m}$ depth $(6-8 \mu \mathrm{M})$. The upper water column $(<100 \mathrm{~m}$ depth) had the lowest nutrient concentrations observed $(<0.9 \mu \mathrm{M}$ $\mathrm{PO}_{4},<9 \mu \mathrm{M} \mathrm{NO} 3$ and $\left.<2 \mu \mathrm{M} \mathrm{Si}(\mathrm{OH})_{4}\right)$ along the entire $\mathrm{BC}$, which coincides with the section where maximum flow of meltwater from the CDIF reaches the BC, forming the fresh and brackish-EW. East of the Diablo Island sill, a disruption 

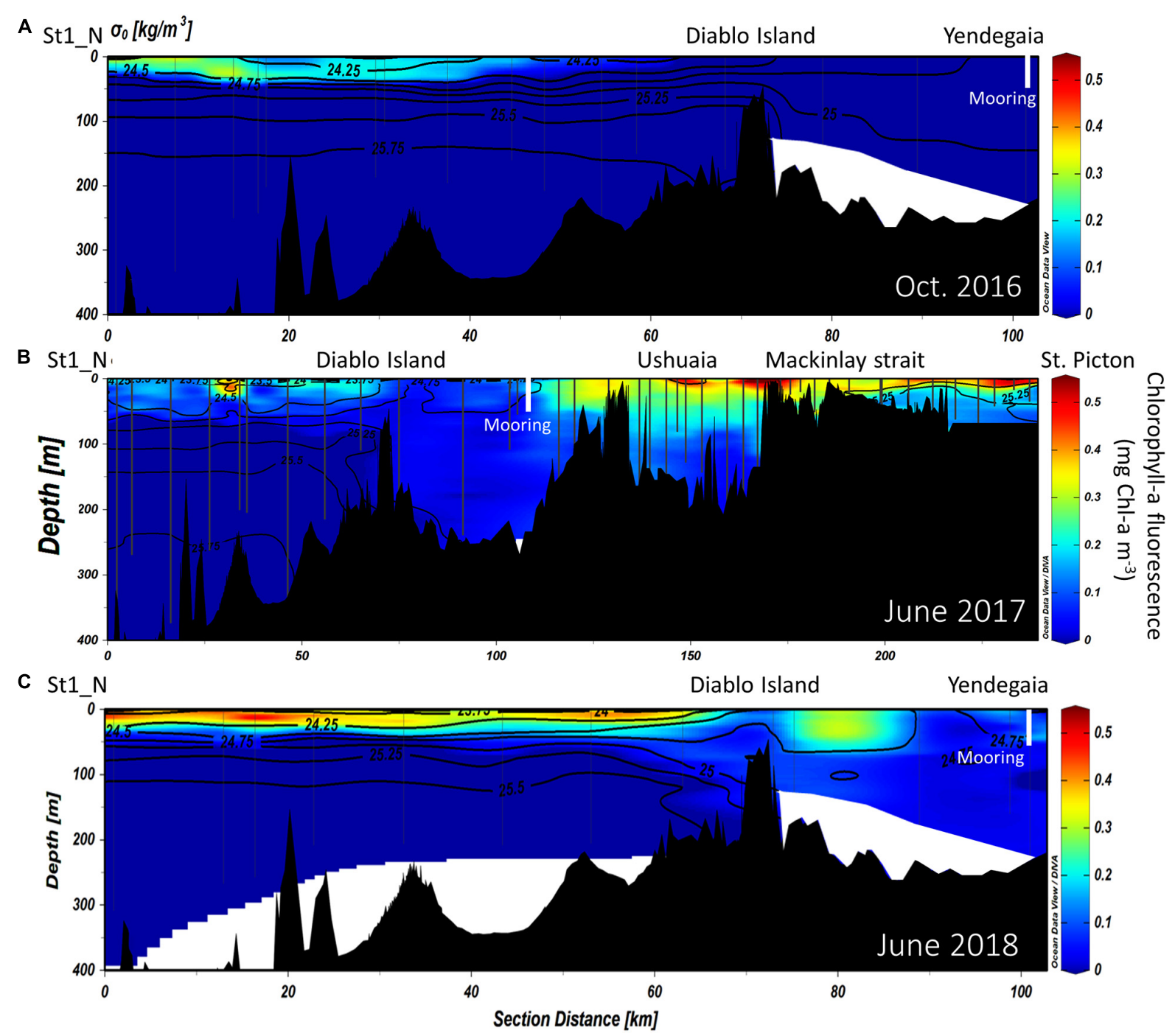

FIGURE 3 | Vertical distribution of chlorophyll-a fluorescence ( $\mathrm{mg} \mathrm{Chl-a} \mathrm{m}^{-3}$ ), overlaid by isopycnals of potential density along the NW branch of the Beagle Channel, during the (A) October 2016, (B) June 2017 and (C) June 2018 campaigns. Interpolated contours are created from individual CTD profiles (positions shown as vertical lines) where St1_N (left side of the figure) represents the westernmost station, and Yendegaia station the eastern part, sampled during 2016 and 2018. During 2017 (B), the westernmost station extends from St1_N to St. Picton at the eastern end of the Beagle Channel. The position of the instrumented mooring is indicated by a vertical white line.

of the vertical distribution of nutrients was observed, causing an almost complete vertical homogenization of nitrate and phosphate through the entire water column of salty-EW which fills the central section of the BC (Figure 7). This relatively homogeneous nutrient distribution (0.9-1.1 $\mu \mathrm{M} \mathrm{PO}_{4}$ and 7.5$10 \mu \mathrm{M} \mathrm{NO}_{3}$ ) extends throughout the water column, along the entire Channel until it reaches the Atlantic Ocean. A significant increase of phosphate was observed at $100 \mathrm{~m}$ depth $(1.47 \mu \mathrm{M}$ $\mathrm{PO}_{4}$ ) and a lesser increase of nitrate was recorded in a station $20 \mathrm{~km}$ west of Mackinlay Strait (Figures 8A,B). Silicic acid concentrations were lowest east of Diablo Island, with some maxima [5-6 $\left.\mu \mathrm{M} \mathrm{Si}(\mathrm{OH})_{4}\right]$ at intermediate depths reaching Mackinlay Strait. Slightly higher silicic acid concentrations were recorded in shallow stations from Ushuaia toward the eastern opening to the Atlantic. Twelve years later, during the CIMAR 16 cruise (Oct-Nov. 2010, Figures 9A-C), the same stations were sampled. Slight increases in phosphate $(\sim 0.1 \mu \mathrm{M}$ $\mathrm{PO}_{4}$, Figure 9A) and nitrate $(\sim 0.5 \mu \mathrm{M} \mathrm{NO}$, Figure 9B) were observed at depth in the western part of the Beagle Channel, following a similar pattern as that observed in 1998. Higher concentrations of phosphate, nitrate and silicic acid were observed at stations where SAAW was present. At the surface, and close to the CDIF, a depletion of nutrients (freshand brackish-EW) was recorded, and east of the Diablo Island sill could be seen a homogenization of nutrients through the water column, with few maxima at depth west of Mackinlay Strait, similar to the pattern observed during the CIMAR 3 cruise. The major difference was the decrease of silicic acid 


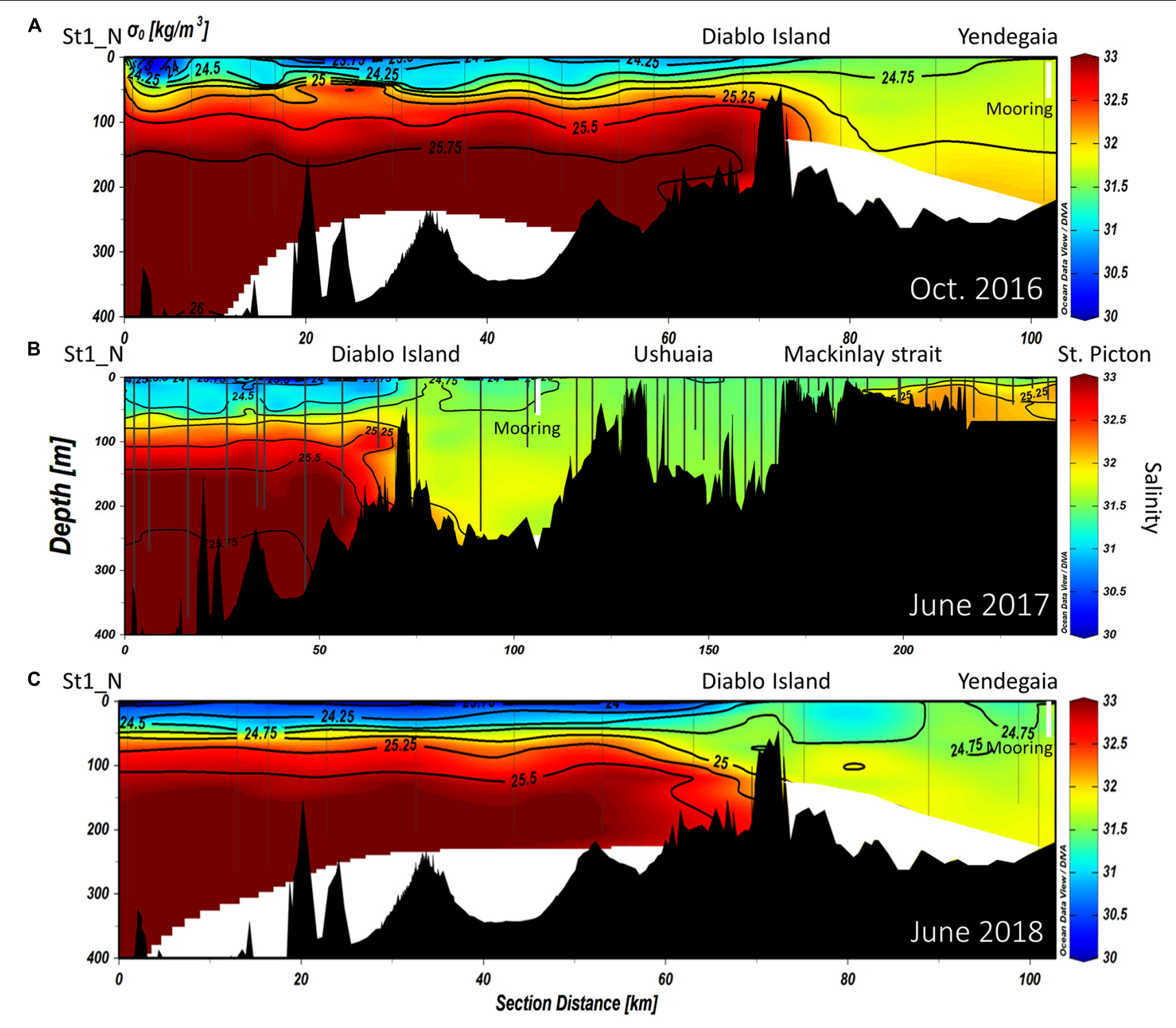

FIGURE 4 | Vertical distribution of salinity (EOS-80), overlaid by isopycnals of potential density along the NW branch of the Beagle Channel during the (A) October 2016, (B) June 2017, and (C) June 2018 campaigns. Interpolated contours are created from individual CTD profiles (positions shown as vertical lines), where St1_N (left side of the figure) represents the westernmost station, and Yendegaia station the eastern part, sampled during 2016 and 2018. During 2017 (B) the westernmost station extends from St1_N to St. Picton at the eastern end of the Beagle Channel. The position of the instrumented mooring is indicated by a vertical white line.

at the surface along the entire transect, with concentrations $<1.5 \mu \mathrm{M}$ in the upper $150 \mathrm{~m}$. The entire Beagle Channel showed a noticeable nitrate limitation which was consistent among all water masses (Figures 10A,B) with a N : P ratio of 8.42 and 8.25 during CIMAR 3 (Figure 10A) and CIMAR 16 (Figure 10B), respectively. In contrast to the $\mathrm{N}: \mathrm{P}$ ratio, the $\mathrm{N}$ : Si ratio showed a differential limitation related to the different water masses (Figures 10C,D). There was a relative silicic acid limitation in SAAW despite its higher nutrient concentration, compared to the mSAAW and whole EW. The fresh and brackish-EW was the water mass with the lowest nutrient concentration, with an $\mathrm{Si}(\mathrm{OH})_{4}: \mathrm{NO}_{3}$ ratio close to 1 during both CIMAR cruises (Figures 10C,D).

\section{Time Series of Temperature and Atmospheric Variables in the Middle Section of the Beagle Channel}

The temporal variability in water and atmospheric temperature at low frequencies was dominated by the annual cycle (Figures 11, 12A-C), which explained $75-89 \%$ and $53 \%$ of the variability, respectively (Table 2). A lower percentage of the temporal variability of the water temperature was explained by the semi-annual cycle (2-5\%). This explains the significant control exerted by summer and winter seasons in the vertical structure of the water column from the surface $(50 \mathrm{~m})$ to $195 \mathrm{~m}$ depth in the middle section of the BC. The influence 


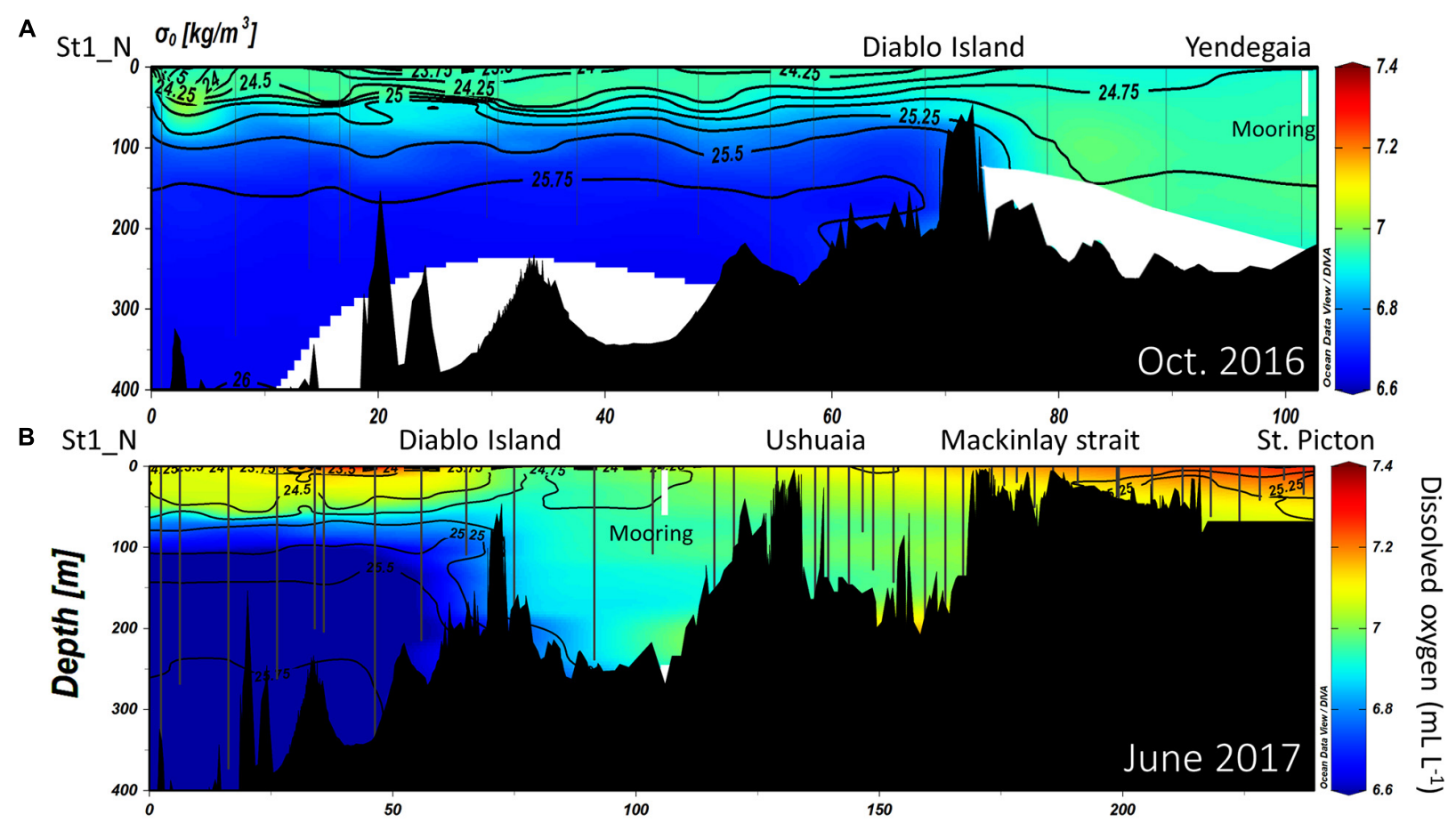

C

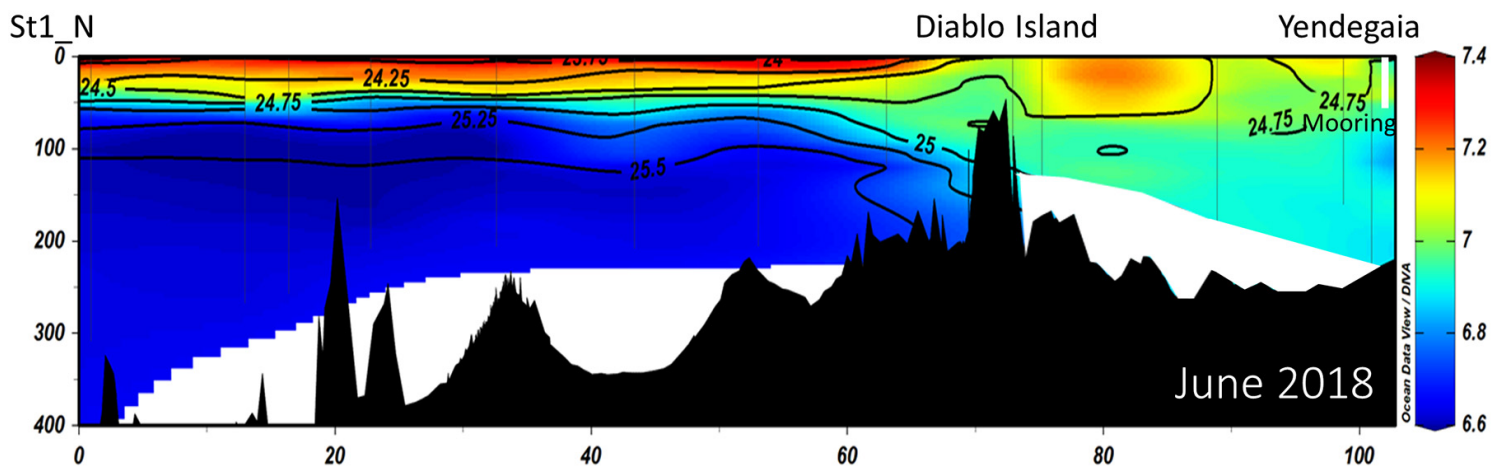

Section Distance [km]

FIGURE 5 | Distribution of dissolved oxygen concentration $\left(\mathrm{mL} \mathrm{L}^{-1}\right)$, overlaid by isopycnals of potential density along the NW branch of the Beagle Channel, during the (A) October 2016, (B) June 2017 and (C) June 2018 campaigns. Interpolated contours are created from individual CTD profiles (positions shown as vertical lines) where St1_N (left side of the figure) represents the westernmost station, and Yendegaia station the eastern part, sampled during 2016 and 2018. During 2017 (B) the westernmost station extends from St1_N to St. Picton at the eastern end of the Beagle Channel. The position of the instrumented mooring is indicated by a vertical white line.

of the annual cycle from the surface $(50 \mathrm{~m})$ to the depths of the Beagle Channel $(195 \mathrm{~m})$ showed a temporal lag of 27 days, and 0 days lag between the surface $(50 \mathrm{~m})$ and the subsurface $(100 \mathrm{~m})$ (Table 3$)$. Correlations among different annual signals, including the atmosphere, showed similar lagged correlations between the annual cycle of the atmosphere and temperatures at 50 and $100 \mathrm{~m}\left(r^{2}=0.85\right.$ and 0.83 , respectively), while atmospheric temperature and measurements taken at $195 \mathrm{~m}$ showed a delay of 63 days at the maximum correlation $\left(r^{2}=0.69\right)$ (Table 3). Once the annual and semi-annual cycles were removed, a peak of energy in ocean temperature variability was explained by high-frequency fluctuations dominated by the semidiurnal tidal periods. Spectral density for the three ocean time series peaked at $12.4 \mathrm{~h}$, although this was more noticeable at $50 \mathrm{~m}$ and $100 \mathrm{~m}$ than at $195 \mathrm{~m}$ (Figure 11). The highest energies in the temperature spectrum were observed at 26 days for $50 \mathrm{~m}$ and $195 \mathrm{~m}$, while a band of energy between 9 and 17 days was noted for the $100 \mathrm{~m}$ temperature time series. A weak cross-correlation was observed between wind magnitude and the residual of ocean temperature (results not shown). The largest temperature gradient from surface $(50 \mathrm{~m})$ to depth $(195 \mathrm{~m})$ was observed during summer and early fall (January to mid-April), reaching $1.5^{\circ} \mathrm{C}$ (Figure 12C). The mooring was positioned off Yendegaia Bay, east of Diablo Island in the middle section of the Beagle Channel, which is less influenced by oceanic inputs. The basin-like structure of 


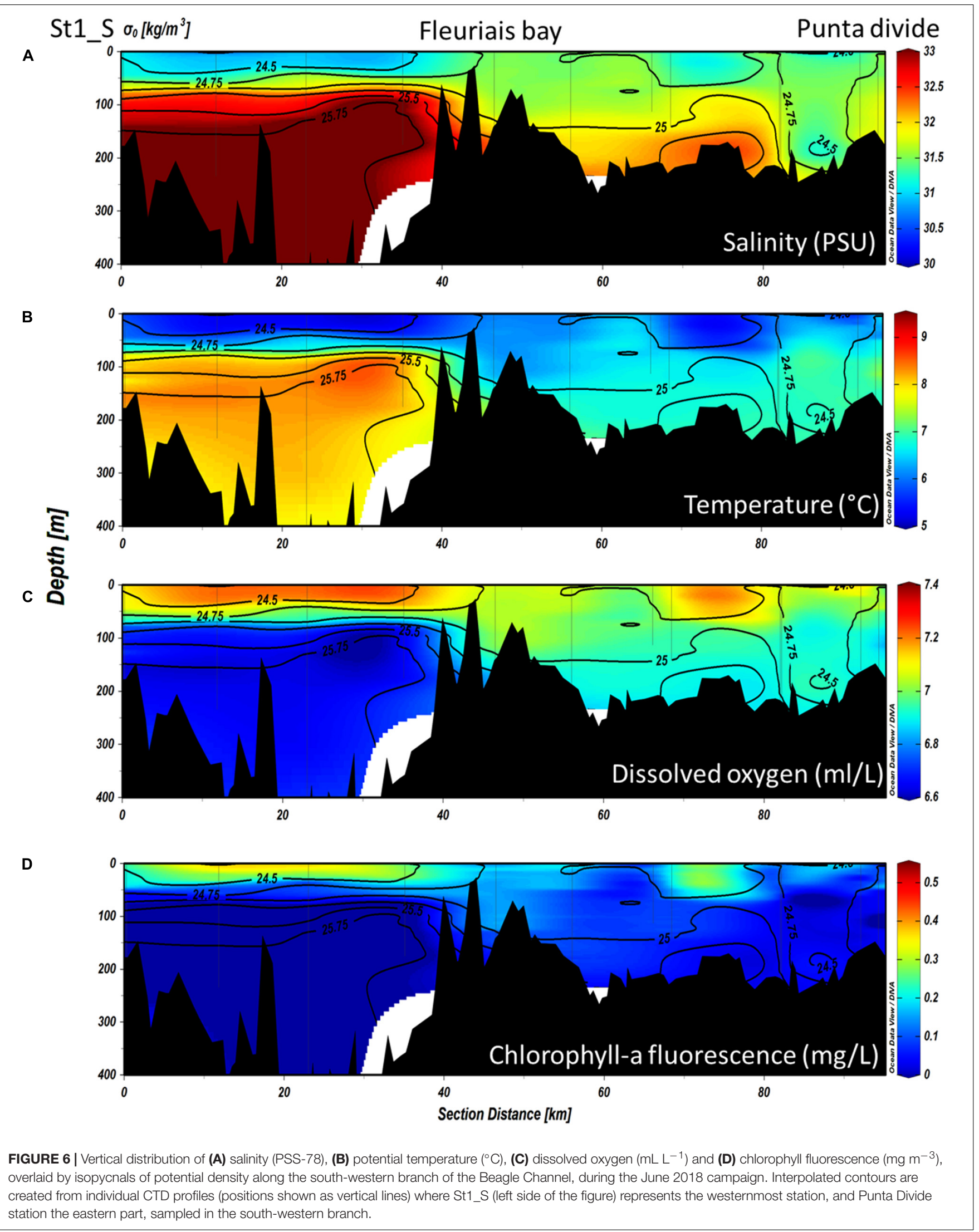




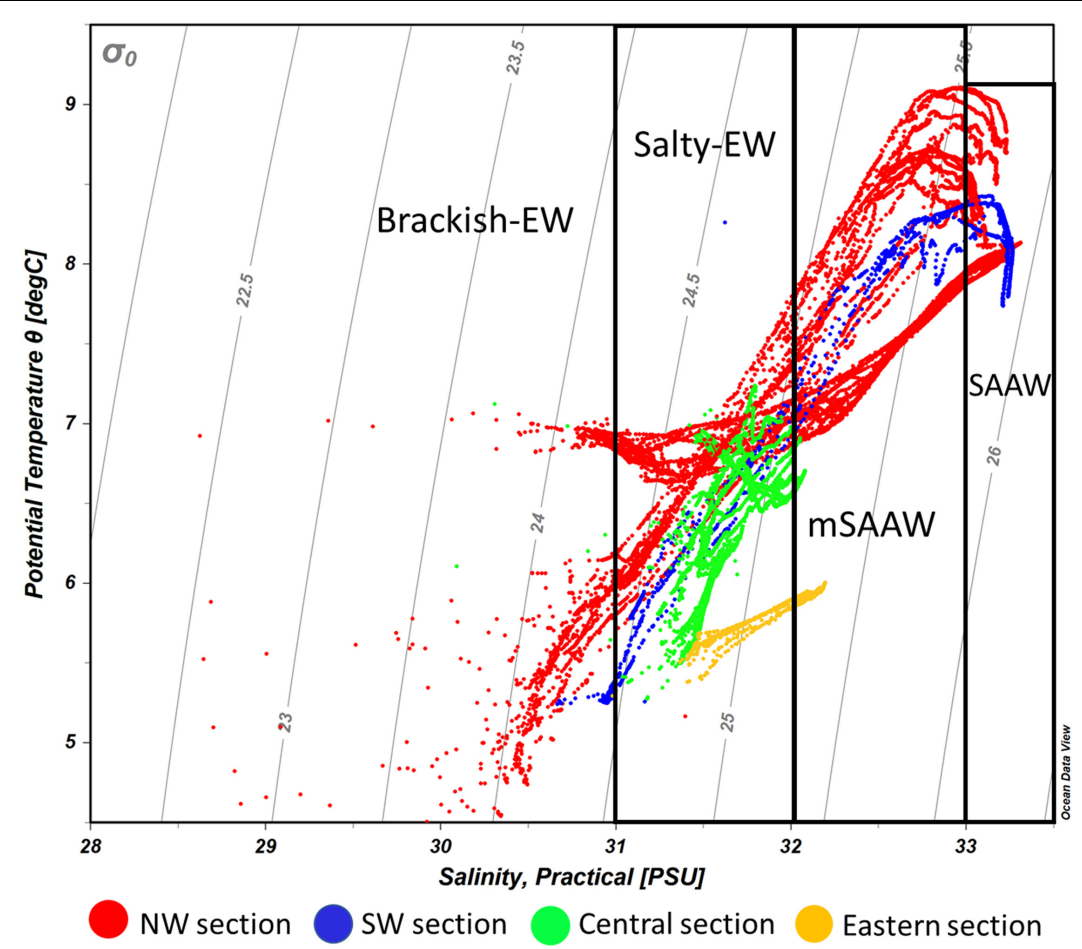

FIGURE 7 | Potential temperature-salinity diagram of all CTD profiles during the different surveys carried out along the Beagle Channel. Light gray lines represent density anomalies $\left(\mathrm{kg} \mathrm{m}^{-3}\right)$. Color codes represent the profiles carried out in each of the described microbasins reported along the Beagle Channel. The NW section (red) includes all the profiles from ST1_N to the Diablo Island sill. The SW section (blue) ranges between ST1_S station and the Fleuriais Bay sill, the central section (green) extends west of the sills in both western branches to the Mackinlay Strait sill, while the eastern section (yellow) indicates all the profiles carried out east of the Mackinlay Strait sill. SAAW, Subantarctic Water; mSAAW, modified Subantarctic water and EW, Estuarine Water which is subdivided into (salty-EW and brackish-EW according to the definition provided by Silva et al. (1998) and Valdenegro and Silva (2003).

this section of the Channel favors retention, and is most likely responsible for the weak temperature gradient found between 50 and $195 \mathrm{~m}$ depth.

\section{DISCUSSION}

\section{Physical and Chemical Water Column Structure of the Beagle Channel}

The hydrography along the Beagle Channel shows a coherence between different sampling events, from the cruises in October 1998 and November 2010, as well as the most recent campaigns in October 2016, July 2017, and July 2018. The system is dominated by (a) the inflow of warm, saline, less oxygenated and nutrientrich waters characteristic of SAAW, to the western section of the Channel, and (b) by the presence of surface fresh-EW with oxygen-rich and nutrient-poor characteristics. The freshEW results from the inflow of cold freshwater from the CDIF glaciers and continental runoff on both shores of the two western branches of the Beagle Channel. Accordingly, a sharp pycnocline develops, separating the lighter fresh-EW from the subsurface tongue of SAAW. The latter fills the entire western section below $75 \mathrm{~m}$ depth from the Pacific entrance as far as the sills at Diablo Island (north-western branch) and Fleuriais Bay (southern branch). However, these shallow sills prevent the spreading of
SAAW toward the east into the middle section of the BC. Lower dissolved oxygen concentrations west of the sills in the NW and SW branches suggest a long residence time and a slow exchange of SAAW and mSAAW. Eastward from these sills, the vertical structure of the water column changes abruptly from stratified to completely mixed from surface to bottom (down to $250 \mathrm{~m}$ depth). The mixed water column has properties that indicate the mixing of fresh-EW with the upper limit of the mSAAW, resulting in salty-EW (31-32) (Sievers et al., 2002; Valdenegro and Silva, 2003). Downstream from these sills, upward pumping of the mSAAW may take place due to Bernoulli aspiration (Kinder and Bryden, 1990), as has been observed for similar environments involving sills along channels (Seim and Gregg, 1997). In fact, Bernoulli aspiration has been registered in the neighboring Magellan Strait (Valle-Levinson et al., 2006), which also connects the Pacific and Atlantic oceans, and provides bathymetric and hydrological along-channel gradients comparable to those of the BC. Briefly, as surface flow accelerates upon encountering the sill, pressure diminishes (Venturi effect), which allows the upward pumping of deep and denser waters; this, in turn, raises the pycnocline. Eventually, the outcrop and overflow of the denser waters toward the downstream side of the sill will be caused by this up-sill suction effect. We presume that only a fraction of the mSAAW is pumped, but it may be enough to increase the density of the brackish-EW near the surface, east of the 


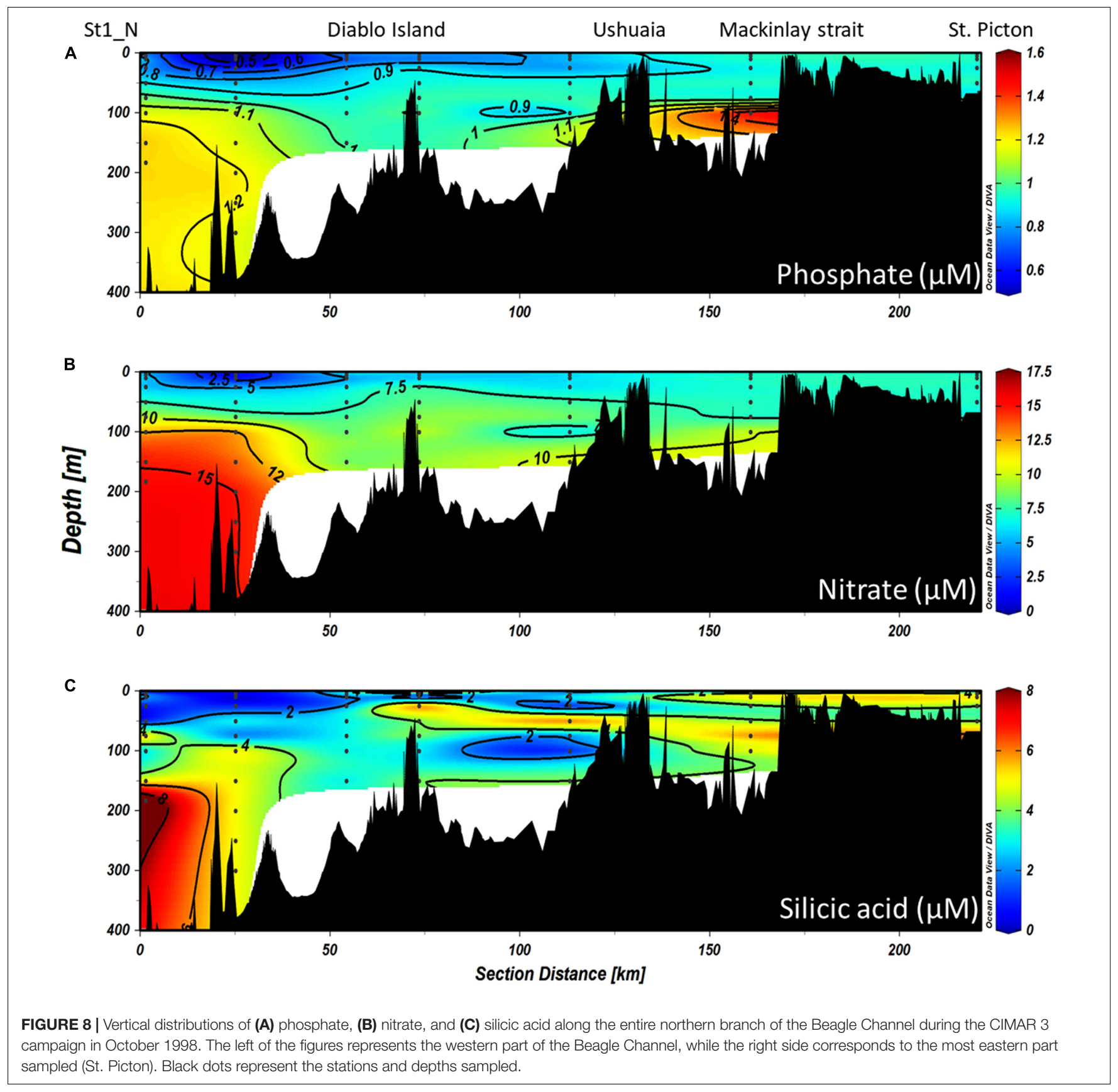

sills, and may thus trigger convective mixing of the entire water column. Such up-sill suction of the SAAW is not evident in our data due to a lack of spatial resolution close to the sill, but previous and more detailed hydrographical profiles conducted along the Diablo Island sill do document this (Figure 2 in Hamamé and Antezana, 1999). Both the up-sill pumping of deep waters and the complete vertical mixing downstream of the sill, observed in Hamamé and Antezana (1999), are consistent with observations from other locations with similar hydrographic settings (Seim and Gregg, 1997; Valle-Levinson et al., 2006). On the other hand, such a suction effect has not been observed in the other major sill to the east, at Gable Island, which may be due to a smoother bathymetric transition and a wider channel in comparison with the sector around Diablo Island. East of Gable Island, the two-layer structure observed corresponds to the outflow of fresher waters from the middle section of the Channel; these overly a tongue of water with distinctive higher temperature and salinity, corresponding to mSAAW. The transport of this less saline surface water from the Beagle Channel has been characterized by the transport of nutrient-depleted and high humic-like components associated with highly degraded terrigenous humic material along the eastern margin of the continent toward the Atlantic Ocean (Garzón et al., 2016). In this way, the entire Beagle Channel can be understood as a dilution 


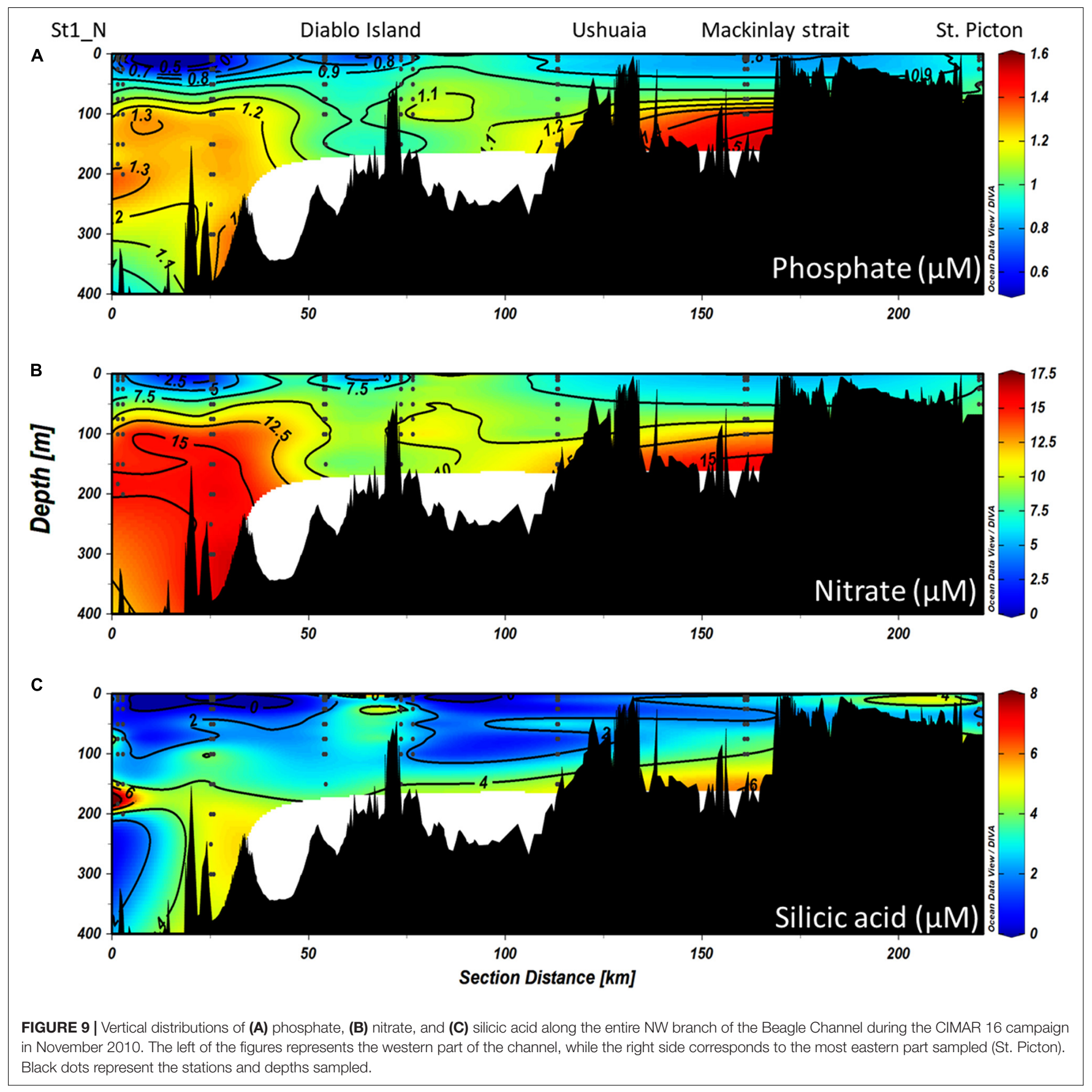

basin, limited by SAAW in the western section and with a less saline mSAAW at the eastern end. The eastward outflow of the middle Beagle Channel may play a role in the total transport of water properties from the Pacific to the Atlantic Patagonian Shelf, which has a major impact on the hydrography, circulation and ecology of that area (Guihou et al., 2020 and references therein).

The temporal variability of temperature at different depths was described for a region off Yendegaia Bay (Figure 12), in the middle section of the Beagle Channel (between the Diablo Island - Fleuriais Bay sills and Mackinlay sill). As mentioned previously, this region is characterized by a relatively homogenous water column (during winter and spring; AugDec), a feature that is permanent in time and changes only slightly during summer months (Dec-Mar). During summer, the atmospheric conditions contribute to both the stratification and the mixing of near-surface waters at the same time. Westerlies increase mainly in November through March (Garreaud et al., 2013), likely contributing to the mixing of the upper water column, whereas higher solar radiation enhances stratification, and hence the relatively homogenous water column, even during summer months (Figure 12C). The most significant temporal driver is dominated by the annual 

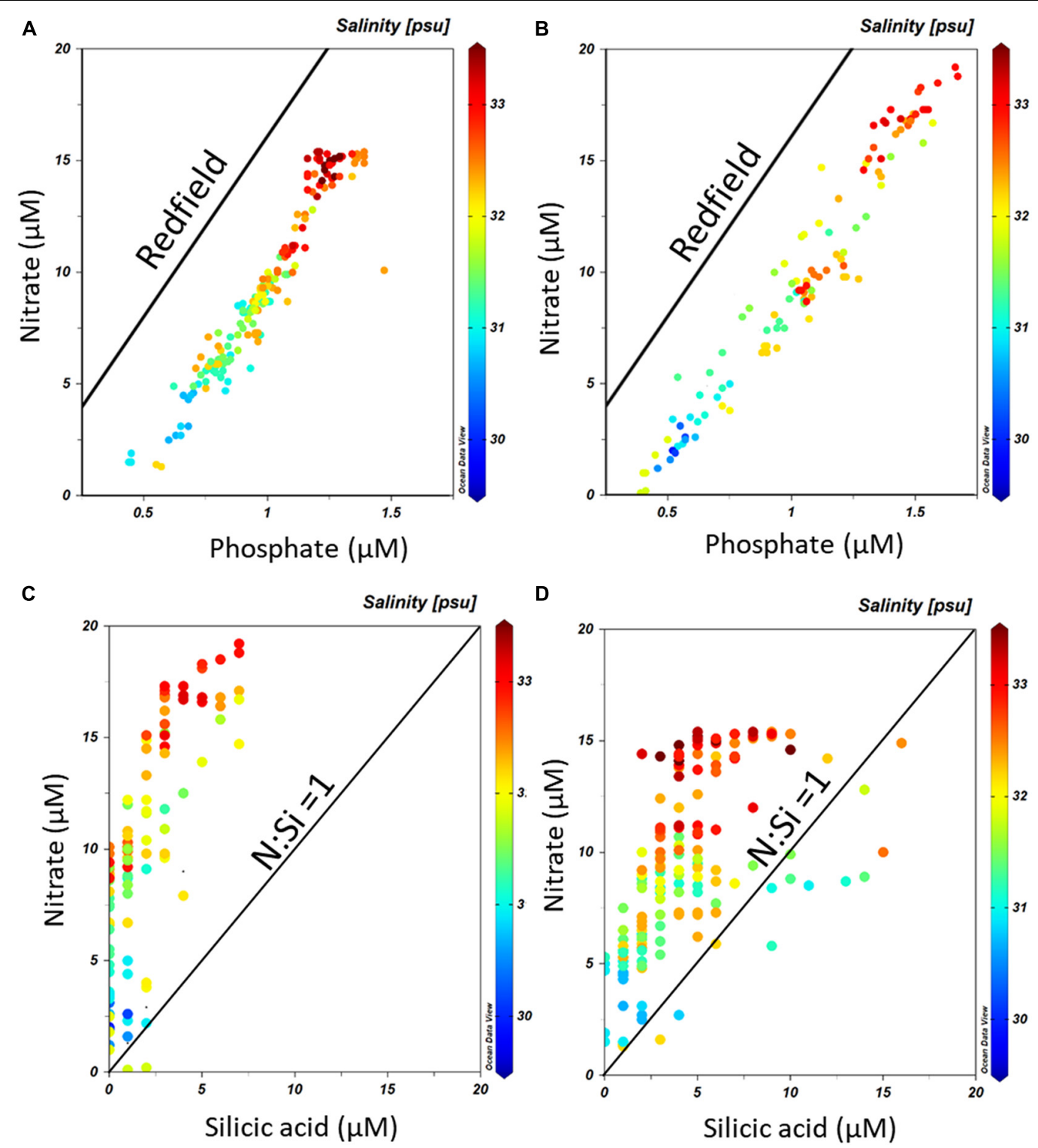

FIGURE 10 | $\mathrm{PO}_{4}-\mathrm{NO}_{3}$ relationships along the Beagle Channel during (A) the CIMAR 3 and (B) the CIMAR 16 cruises, during October 1998 and November 2010 , respectively. The solid line indicates the Redfield ratio (1:16). Si(OH) $)_{4}-\mathrm{NO}_{3}$ relationships along the Beagle Channel during (C) the CIMAR 3 and (D) the CIMAR 16 cruises. The solid line indicates the optimum Si(OH) $4: \mathrm{NO}_{3}$ for diatoms, according to Ragueneau et al. (2000). The color bar represents the salinity (PSS-78) recorded at each sampling point.

signal, followed by higher frequencies dominated by semidiurnal tides (D’Onofrio et al., 1989).

\section{Chemical Features Along the Beagle Channel}

In the Beagle Channel, the highest nutrient concentrations are associated with the inflow of SAAW along the western section of the Channel, while at the surface, nutrient-poor waters are formed by river and glacier runoff. This structure is common to the Patagonian fjords (Silva and Vargas, 2014; Vargas et al., 2018; Cuevas et al., 2019). Generally speaking, this two-layer structure promotes the development of moderate phytoplankton biomass

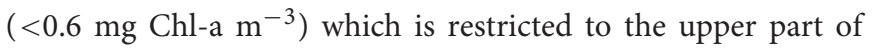
the pycnocline, where diffusion and turbulence favor vertical transport of nutrients from the SAAW toward the upper water column, thus promoting phytoplankton growth (Hamamé and Antezana, 1999; Cuevas et al., 2019). It must be noted that most of the cruises were carried out during the austral winter (July), therefore low phytoplankton biomass is to be expected due to light limitation (Almandoz et al., 2011). Similarly, the sills in the Channel may play an important role in the mixing of the entire water column (mSAAW and brackish-EW), which in turn disrupts the vertical structure of the water column from surface to bottom. This water mixing moves phytoplankton cells 


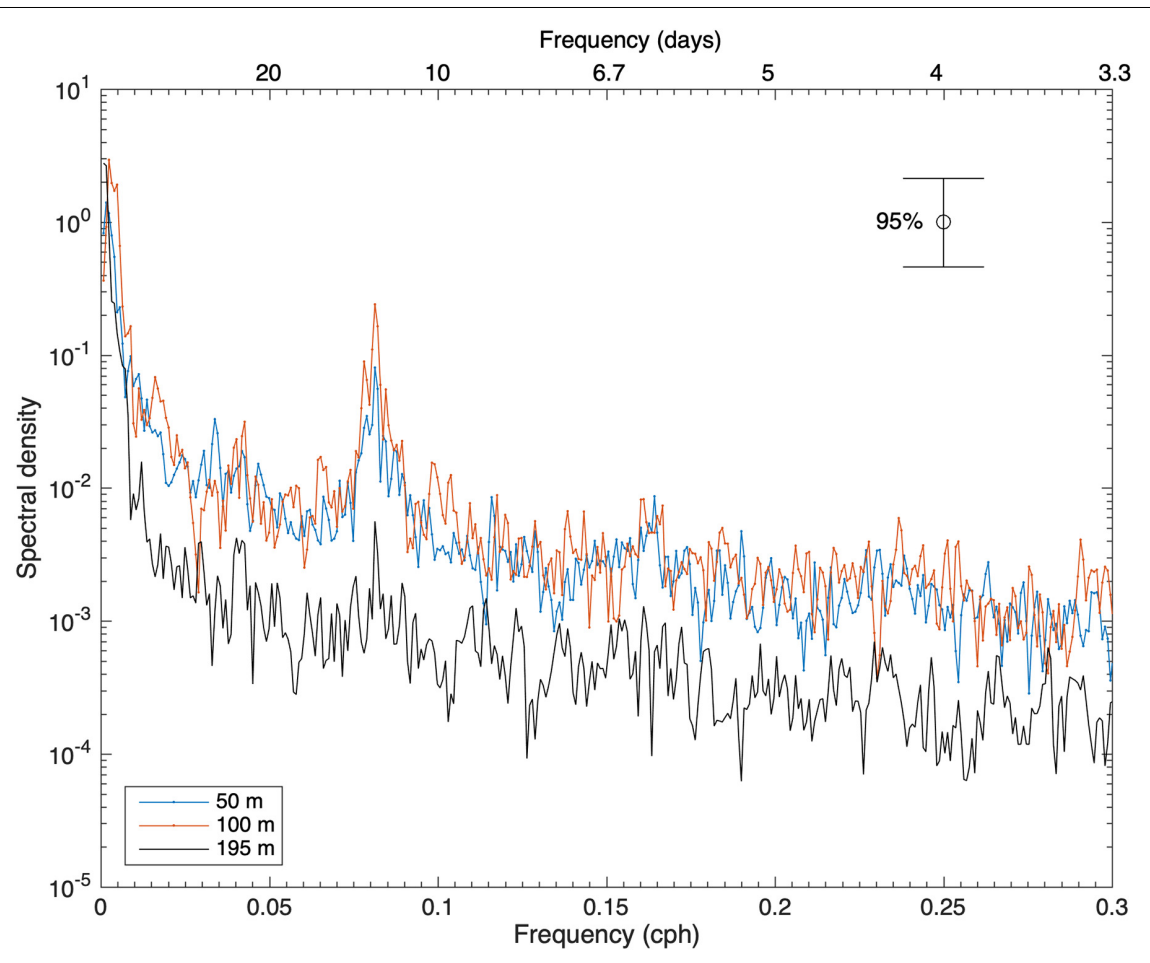

FIGURE 11 | Spectral densities of ocean temperature at 50, 100, and $195 \mathrm{~m}$. Frequency is in cycles per hour (cph) (bottom horizontal axis) and period in days (top horizontal axis). A significance level of $95 \%$ was used.

throughout the entire water column, displacing them at times below the photic layer, which in turn reduces light availability and further limits primary production and phytoplankton growth. However, even during the austral spring (October 2016), phytoplankton biomass did not increase and high Chla fluorescence was confined to a small area at the NW branch, where larger inputs of freshwater were observed (Figures 3A-C). Similarly, east of Ushuaia where bathymetry becomes shallower, higher fluorescence was recorded (Figure 7B). The latter may be the consequence of a resuspension of nutrients from the shallow sediments at Mackinlay Strait, as well as a potential inflow of mSAAW along the east entrance of the BC. This water mass flows over a relatively wide $(150 \mathrm{~km})$ and shallow $(<100 \mathrm{~m})$ continental platform where it can carry nutrients toward the Beagle Channel, promoting primary production. Unfortunately, current measurements along the Beagle Channel are scarce, and are mainly limited to surface currents in the middle section of the Channel (Balestrini et al., 1990). In order to reveal the role of mSAAW on the biogeochemistry and productivity of the eastern section of the $\mathrm{BC}$, the extent and recurrence of mSAAW intrusions across the eastern section should be assessed in the near future.

The productivity of southern Patagonia follows a pronounced seasonal pattern, with an increase in biomass starting in

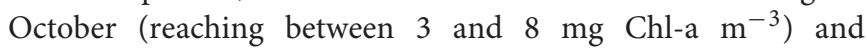
lasting until March (Iriarte et al., 2001; Almandoz et al., 2011). Photosynthetically active solar radiation then decreases (Cuevas et al., 2019) and chlorophyll biomass diminishes to $<0.5 \mathrm{mg} \mathrm{m}^{-3}$
(Almandoz et al., 2011). Phytoplankton in the Beagle Channel may be limited primarily by low irradiance, or by the low nutrient concentrations in fresh and brackish-EW. The low $\mathrm{N}$ : $P$ ratio through the entire Beagle Channel likely causes nitrate limitation (Figures 10A,B), which restricts phytoplankton growth. Indeed, nutrient limitation, and especially nitrate limitation, is a common feature hampering phytoplankton growth in the upper waters of southern Patagonia (Iriarte et al., 2001; Valdenegro and Silva, 2003; Iriarte et al., 2013; Vargas et al., 2018; Cuevas et al., 2019). In some areas of the Beagle Channel there may also be a silicic acid colimitation (Figures 10C,D). The low concentrations of silicic acid in surface waters is likely associated with glacier meltwater inputs. The concentration of silicic acid in coastal runoff depends on variables controlling weathering processes, such as temperature, precipitation, lithogenic structure of the soil, types of vegetation, transport time, etc. The Patagonian freshwater input south of $51{ }^{\circ} \mathrm{S}$ is characterized by low levels of silicic acid, due to the small mineral area exposed, low temperatures, reduced runoff, and low volcanic activity, which combine to reduce the weathering flux of silicates to coastal waters (Torres et al., 2011, 2014). Diatoms tend to dominate phytoplankton communities under high phosphate $\left(\mathrm{PO}_{4}\right)$, nitrate $\left(\mathrm{NO}_{3}\right)$ and silicic acid $\left(\mathrm{Si}(\mathrm{OH})_{4}\right)$ concentrations (Sarthou et al., 2005) with a $\mathrm{Si}(\mathrm{OH})_{4}: \mathrm{NO}_{3}$ uptake ratio of 1:1 under no iron limitation (Ragueneau et al., 2000). The stoichiometry of macronutrients recorded within the Beagle Channel favors other phytoplankton groups rather than diatoms, which explains why small phytoflagellates and other 

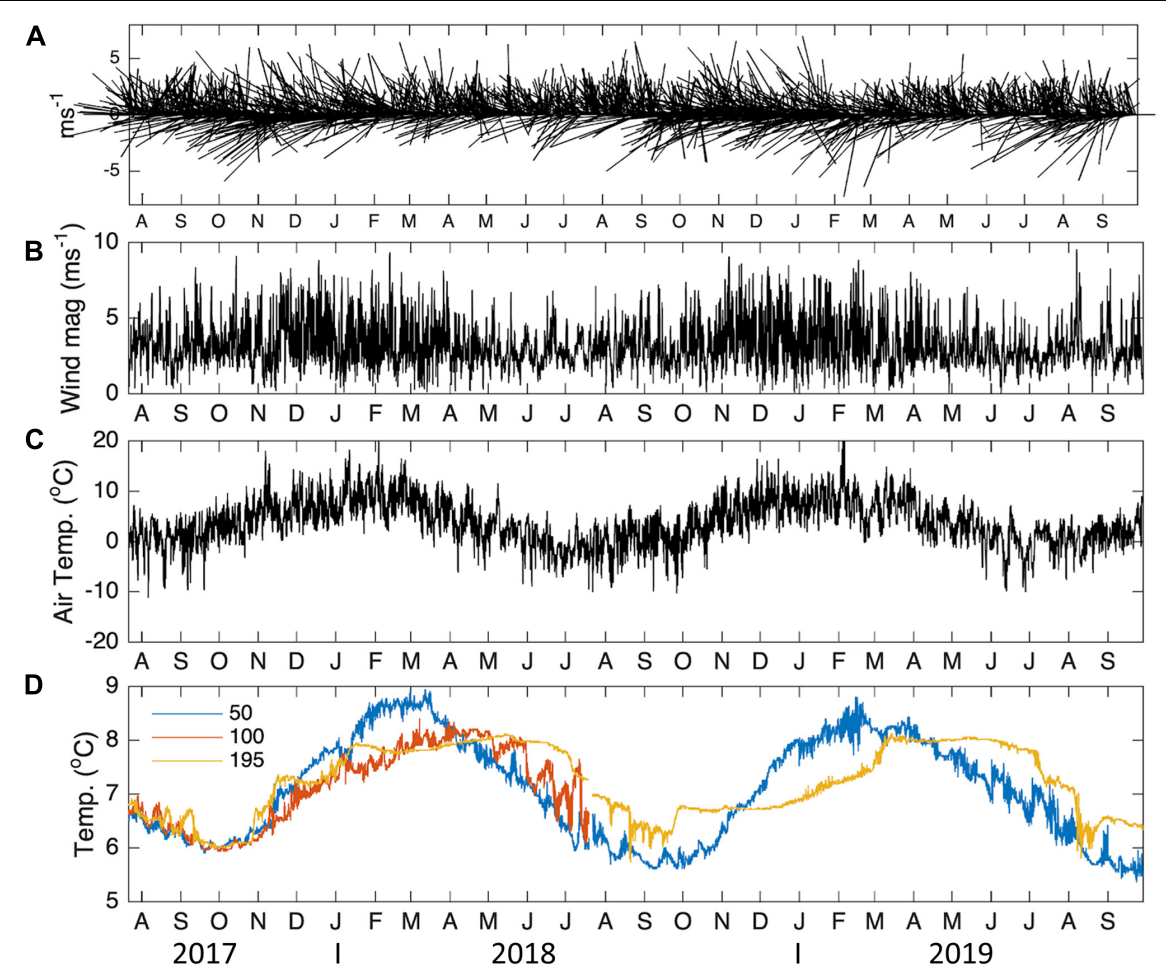

FIGURE 12 | Temporal variability of daily (A) wind vectors, (B) wind magnitude, (C) air temperature and (D) ocean temperature, at 50, 150, and 195 m depth. The wind stick plot reports the wind in $\mathrm{m} \mathrm{s}^{-1}$ and the direction from which it originates. Temperatures are expressed in ${ }^{\circ} \mathrm{C}$. Wind and atmospheric temperature were obtained from the ERA5 reanalysis corresponding to the location closest to the mooring.

pico- and nanophytoplankton tend to dominate the phytoplankton community in the Beagle Channel (Almandoz et al., 2011). Likewise, the low concentration of nutrients in the surface waters may partially drive the overall low phytoplankton biomass recorded in the Channel.

During the 2017 cruise, the eastern section of the Channel showed an increase in surface Chl-a fluorescence east of Ushuaia where the seafloor rises, reducing the depth of the water column. This bathymetry may favor the resuspension of nutrient-rich sediments, while an increased human footprint may produce a nutrient-rich runoff compared to the western part of the Beagle Channel (Torres et al., 2009; Amin et al., 2011). As observed during the CIMAR 3 and 16 cruises, higher nutrient concentrations occur at depth in the eastern section of the Channel, coinciding with the region where higher Chla fluorescence was recorded in 2017. The only time series report on the eastern section of the Channel (Almandoz et al., 2011) shows a clear seasonality in nutrient concentration, with higher nutrient concentrations at surface during winter $\left(\mathrm{NO}_{3}\right.$ 10-16 $\mu \mathrm{M}, \mathrm{PO}_{4} 2 \mu \mathrm{M}$ and $\mathrm{SiOH} 4-8 \mu \mathrm{M}$ ), which is consistent with our observations. During spring and summer (OctoberMarch), nutrients tend to drop below $2 \mu \mathrm{M}\left(\mathrm{NO}_{3}\right), 1 \mu \mathrm{M}\left(\mathrm{PO}_{4}\right)$, and $3 \mu \mathrm{M}(\mathrm{SiOH})$, which can be associated with phytoplankton uptake when phytoplankton biomass may reach $9 \mu \mathrm{g}$ Chla $\mathrm{L}^{-1}$ (Almandoz et al., 2011). Almandoz et al. (2011) also found species of benthic diatoms in the eastern section of the Channel (west of Mackinlay Strait), which further confirms the presence of resuspension in this area, enabling the advection of nutrients to upper waters in this shallow section of the Channel. However, we cannot rule out the possibility of episodic intrusions of mSAAW at depth from the east, which may also transport nutrients into the middle section of the Beagle Channel. The advection of mSAAW may, in fact, be important in both branches of the western section of the Channel due to the presence of deep submarine canyons which may enable the direct inflow of mSAAW. Unlike in the eastern section of the Channel, the deep bathymetry $(>200 \mathrm{~m})$ of the western section may hamper the transfer of mSAAW nutrients into surface waters, which in turn may limit phytoplankton growth and the overall effectiveness of deep nutrient inflow through the western end of the Beagle Channel.

The presence of four microbasins along the Beagle Channel creates distinct semi-isolated systems with particular physicochemical properties that are subject to the interplay of SAAW and mSAAW at depth and fresh-EW at the surface. This favors the formation of particular biological niches with both chlorophyll and nutrient discontinuities (Hamamé and Antezana, 1999) and distinctive planktonic communities (Palma and Silva, 2004), reinforcing the idea that these discontinuities can produce ecosystems which are structurally and functionally unique. Further efforts should be focused on increasing processoriented studies within each of the semi-enclosed basins, as well as on improving spatial and temporal monitoring procedures to shed light on the dynamics of this interoceanic passage. 
TABLE 2 | Percentage explained by annual and semi-annual signals in atmospheric temperature (AT), ocean temperature (T50, T195), and wind magnitude (Wind Mag), for the two-year time series.

\begin{tabular}{lccccc}
\hline Temporal signal & T50 & T100(*) & T195 & AT & Wind Mag \\
\hline 182 days & $1.60 \%$ & $8.00 \%$ & $5.40 \%$ & $0.20 \%$ & $0.60 \%$ \\
365 days & $88.70 \%$ & $49.60 \%$ & $74.90 \%$ & $52.60 \%$ & $4.80 \%$ \\
\hline
\end{tabular}

*The percentage explained by annual and semi-annual signals for $100 \mathrm{~m}$ ocean temperature was done for only one year of data.

TABLE 3 | Cross-correlation analysis between the annual and semi-annual signal of atmospheric temperature (AT) and ocean temperatures at 50, 100, $195 \mathrm{~m}$ and lags (in days) associated with the maximum correlations observed using a $95 \%$ confidence level.

\begin{tabular}{lcc}
\hline Variable pairs & $\begin{array}{c}\text { Correlation } \\
\text { coefficient }\end{array}$ & Lag (days) \\
\hline AT-T50 & 0.8474 & 25.46 \\
AT-T100 & 0.8306 & 28.38 \\
AT-T195 & 0.6893 & 63.12 \\
T50-T100 & 0.9208 & 0 \\
T50-T195 & 0.8824 & 26.62 \\
T100-T195 & 0.777 & 35.83 \\
\hline
\end{tabular}

\section{Expected Future Changes in the Beagle Channel and Possible Consequences}

Currently, most of the Beagle Channel is still subject to relatively low human pressure, with the exception of the two cities in the eastern section: Ushuaia (67,600 inhabitants, Census 2015) and Puerto Williams (1,868 inhabitants, Census 2018). Currently, the region is facing a major threat due to the expansion of aquaculture toward higher latitudes. This concerns the salmon industry in particular, and can alter nutrient stoichiometry, as has already been observed in central and northern Chilean Patagonia (Iriarte, 2018). In the near future, local anthropogenic activities (city wastewater, industrial activities, navigation and aquaculture) may exert an important impact on the chemical composition of the Beagle Channel waters, and even alter biological productivity, if proper management plans are not implemented now. The major impacts on this region are associated with increased nutrient inputs (especially nitrogen) due to changes in land-use and aquaculture. Microcosm experiments in northern Patagonia have shown that the addition of ammonium due to aquaculture promotes the development of large amounts of autotrophic biomass and bacterial production (Olsen et al., 2017), which could lead to oxygen depletion events in the photic layer. These events, even when sporadic, will affect the entire pelagic community, causing major changes both within the trophic webs of the ecosystem and to the biogeochemistry of the water column and benthos. Due to the pronounced seasonality of marine high latitude ecosystems, the productive period is limited to spring and summer (from October to mid-March, Almandoz et al., 2011) when the net uptake of $\mathrm{CO}_{2}$ exceeds the community respiration, creating a net sink of $\mathrm{CO}_{2}$ (Torres et al., 2011). During the remaining months, Chl-a concentration falls to $<1 \mu \mathrm{g}$ Chl-a $\mathrm{L}^{-1}$ (Almandoz et al., 2011) and heterotrophic processes tend to dominate (e.g., Torres et al., 2011; Vergara-Jara et al., 2019). In a scenario of intensive aquaculture, we might expect higher loads of dissolved and particulate organic matter as well as an increase in nutrients ( $\mathrm{N}$ and $\mathrm{P}$ mainly), which will primarily be remineralized by heterotrophic organisms, thus increasing $\mathrm{pCO}_{2}$ levels and altering the carbonate chemistry of the seawater. On the other hand, increasing loads of inorganic $\left(\mathrm{NH}_{4}, \mathrm{NO}_{3}\right)$ and organic nitrogen might also enhance the recurrence of Harmful Algal Blooms (HABs) (Anderson et al., 2002) of the type that already occur in the area (Almandoz et al., 2014, 2019). The current state of the Beagle Channel, and in particular east of the Punta Divide, is particularly vulnerable due to the reduced water exchange between basins. This reduced exchange is thought to promote eutrophication, while vertical mixing of the water column may favor the resuspension of cysts of toxic phytoplankton from the sediments. HABs (especially Alexandrium catenella) have been monitored by the Chilean Institute for Fisheries Development (IFOP) since 2006 along the Beagle Channel. HABs have occurred at several locations along the Channel, particularly during the onset of summer (Benavides et al., 1995). One of the largest HABs was recorded between November 1991 and April 1992; it started close to Ushuaia and then spread westward during its development. This HAB caused a high toxicity in blue mussels $\left(80 \mu \mathrm{g}\right.$ STXeq. $\left.100 \mathrm{~g}^{-1}\right)$ that lasted until the end of 1992 (Benavides et al., 1995). If nutrient inputs increase in the future (e.g., city sewage, aquaculture inputs), it is likely that the middle and eastern sections of the Channel will be affected. In addition, the current decrease in rainfall observed over the last decades during spring and summer in the Magellan region (GonzálezReyes et al., 2017) may trigger the development of HABs in the Beagle Channel, as has already been the case in northern Patagonia (León-Muñoz et al., 2018).

Similarly, changes in glacial meltwater runoff, as well as sea water temperature and stratification, may alter the occurrence of HABs in the western part of the Beagle Channel in the near future (e.g., Richlen et al., 2016; León-Muñoz et al., 2018; Joli et al., 2018). Previous studies have shown that the warming of the Beagle Channel waters will reduce the abundance of diatoms, which will shift the composition of the plankton community and may, in turn, favor other phytoplankton groups (Moreau et al., 2014). These changes may reduce the efficiency of the biological carbon pump in the Beagle Channel due to the loss of fast sinking diatom frustules, while other groups more prone to developing into HABs (e.g., dinoflagellates) might be favored by the reduction of diatom biomass.

Observations from the last four decades indicate that the prevailing zonal (west-east) wind in the region has increased its intensity to a rate of $0.2-0.3 \mathrm{~m} \mathrm{~s}^{-1}$ per decade (Garreaud et al., 2013). This increase has been related to an increase in rainfall at a rate of $200 \mathrm{~mm}$ per decade in areas south of $50^{\circ} \mathrm{S}$. In this region, low frequency forcing is strongly influenced and dominated by the SAM, which in recent decades has shifted to positive polarities, favoring higher atmospheric temperatures. Since 1990, records of rainfall in Punta Arenas have shown a significant increase over the austral winter months (June) and a decrease during spring and summer (González-Reyes et al., 2017). These fluctuations reflect an increase in the minimum air 
temperature and an intensification of the effect of the circumpolar atmospheric circulation, respectively (Garreaud et al., 2013). The IPCC projections for atmospheric conditions in the Magellan region in 2050 indicate that, under a business-as-usual scenario (RCP 8.5 scenario), rainfall will increase by about $10 \%$ and the average air temperature will rise by $0.5^{\circ} \mathrm{C}$, strengthening and confirming the present-day trends.

The hydrography of the Beagle Channel is primarily constrained by the presence of sills at both ends. This bathymetric configuration is characterized by limited exchange which restricts the permanent flow, in turn generating specific physical, chemical and biological conditions. This situation makes the Beagle Channel a remarkable study area, where each basin has its own dynamics which likely respond differently to external forcing and stressors, such as nutrient discharge, freshwater inputs from glacier melting and rainfall, and large-scale processes such as atmospheric oscillations (SAM, ENSO). Further research should focus on studying the circulation along different sections of the Beagle Channel, as well as on implementing and validating coupled atmosphere-ocean-glacial models in order to determine residence times and identify regions of higher retention. Such studies will help to better understand the main circulation features, forcings, and the spatio-temporal changes that currently drive Beagle Channel dynamics, while establishing a baseline to monitor and manage potential threats to this still nearpristine environment.

\section{DATA AVAILABILITY STATEMENT}

The datasets presented in this study can be found in online repositories. The names of the repository/repositories and accession number(s) can be found below: https://doi.pangaea.de/ 10.1594/PANGAEA.934063 and https://doi.pangaea.de/10.1594/ PANGAEA.934046.

\section{AUTHOR CONTRIBUTIONS}

RG planned and led the Chilean campaigns between 2016 and 2017 in which JH, JG-V, EA, and HG participated. JG-V led the

\section{REFERENCES}

Abram, N. J., Mulvaney, R., Vimeux, F., Phipps, S. J., Turner, J., and England, M. H. (2014). Evolution of the southern annular mode during the past millennium. Nat. Clim. Change 4, 564-569. doi: 10.1038/nclimate2235

Almandoz, G. O., Cefarelli, A. O., Diodato, S., Montoya, N. G., Benavides, H. R., Carignan, M., et al. (2019). Harmful phytoplankton in the Beagle Channel (South America) as a potential threat to aquaculture activities. Mar. Pollut. Bull. 145, 105-117. doi: 10.1016/j.marpolbul.2019.05.026

Almandoz, G. O., Hernando, M. P., Ferreyra, G. A., Schloss, I. R., and Ferrario, M. E. (2011). Seasonal phytoplankton dynamics in extreme southern South America (Beagle Channel, Argentina). J. Sea Res. 66, 47-57. doi: 10.1016/j. seares.2011.03.005

Almandoz, G. O., Montoya, N. G., Hernando, M. P., Benavides, H. R., Carignan, M. O., and Ferrario, M. E. (2014). Toxic strains of the Alexandrium ostenfeldii complex in southern South America (Beagle Channel, Argentina). Harmful Algae 37, 100-109. doi: 10.1016/j.hal.2014.05.011
2018 campaign. JH and JG-V preformed and processed all the CTDs casts of the campaign performed by the IDEAL center. AP preformed the time series analysis from the fixed station, as well as the atmospheric data. JM compiled and processed the hydrographic data from the Argentinian section of the $\mathrm{BC}$ and led the Houssay-17 campaign where XF-M, XD, and FB participated. All authors contributed to discussion and writing of the manuscript.

\section{FUNDING}

This research was supported by the Agencia Nacional de Investigación y Desarrollo (ANID) through project FONDAP IDEAL, grant number 15150003, projects HYDRO-USHUAIA (ECOS-SUD/MINCyT) and P-UE 2016: 22920160100077CO (CONICET), and by the German Federal Ministry of Education and Research (BMBF), grant number LAT16STRUC-039. The project leading to this publication has received funding from the Excellence Initiative of Aix-Marseille University $A^{\star}$ Midex, a French "Investissements d'Avenir programme" AMX-19-IET-012.

\section{ACKNOWLEDGMENTS}

We would like to thank the Chilean and Argentinean Navy for providing bathymetry charts, as well as the captain and crew of the Forrest vessel for their professional assistance and help during sampling procedures. We acknowledge the support of Prefectura Naval Argentina, MINCYT and thank Gustavo Ferreyra for making possible the cruise onboard M/O Bernardo Houssay and two reviewers for valuable comments on the manuscript. We would like to express our gratitude and our respects to Nelson Silva who passed away in August 2020. His pioneer work and passion for chemical oceanography research in Patagonia ecosystems opened new avenues for those of us who came after him.

Amin, O., Comoglio, L., Spetter, C., Duarte, C., Asteasuain, R., Freije, R. H., et al. (2011). Assessment of land influence on a high-latitude marine coastal system: Tierra del Fuego, southernmost Argentina. Environ. Monit. Assess. 174, 63-73. doi: 10.1007/s10661-010-1493-5

Anderson, D. M., Glibert, P. M., and Burkholder, J. M. (2002). Harmful algal blooms and eutrophication: nutrient sources, composition, and consequences. Estuaries 25, 704-726. doi: 10.1007/bf02804901

Atlas, E., Hager, S., Gordon, L., and Park, P. (1971). A Practical Manual for Use of the Technicon Autoanalyzer in Sea Water Nutrient Analyses. Technical Report. Corvallis, OR: Oregon State University, 215.

Balestrini, C. F., Vinuesa, J., Speroni, J., Lovrich, G., Mattenet, C., Cantú, C., et al. (1990). Estudio de las Corrientes Marinas en los alrededores de la Península Ushuaia. Buenos Aires: CADIC-Centro Austral de Investigaciones Científicas, Comunicación Científica.

Balestrini, C., Manzella, G., and Lovrich, G. A. (1998). Simulación de Corrientes en el Canal Beagle y Bahía Ushuaia, Mediante un Modelo Bidimensional. Inf Téc $N^{\circ}$ 98. Buenos Aires: Servicio de Hidrografía Naval, 1-58. 
Benavides, H., Prado, L., Díaz, S., and Carreto, J. I. (1995). “An exceptional bloom of Alexandrium catenella in the Beagle Channel, Argentina," in Harmful Algal Blooms, eds P. Lassus, G. Arzul, E. Erard, P. Gentien, and C. Marcaillou (Paris: Lavoisier), 113-119.

Bonjean, F., and Lagerloef, G. S. E. (2002). Diagnostic model and analysis of the surface currents in the tropical Pacific Ocean. J. Phys. Oceanogr. 32, 2938-2954. doi: 10.1175/1520-0485(2002)032<2938:dmaaot>2.0.co;2

Brun, A. A., Ramirez, N., Pizarro, O., and Piola, A. R. (2020). The role of the Magellan Strait on the southwest South Atlantic shelf. Estuar. Coast. Shelf Sci. 237:106661. doi: 10.1016/j.ecss.2020.106661

Bujalesky, G. G. (2011). The flood of the Beagle Valley (11000 YR B.P.), Tierra del Fuego. Anal. Inst. Patagonia 39, 5-21. doi: 10.4067/s0718-686x2011000100001

Buschmann, A. H., Cabello, F., Young, K., Carvajal, J., Varela, D. A., and Henríquez, L. (2009). Salmon aquaculture and coastal ecosystem health in Chile: analysis of regulations, environmental impacts and bioremediation systems. Ocean Coast. Manag. 52, 243-249. doi: 10.1016/j.ocecoaman.2009.03. 002

Cuevas, L. A., Tapia, F. J., Iriarte, J. L., González, H. E., Silva, N., and Vargas, C. A. (2019). Interplay between freshwater discharge and oceanic waters modulates phytoplankton size-structure in fjords and channel systems of the Chilean Patagonia. Prog. Oceanogr. 173, 103-113. doi: 10.1016/j.pocean.2019.02.012

D’Onofrio, E., Orsi, A., and Locarnini, R. (1989). Estudio de Marea en la Costa de Tierra del Fuego. Servicio de Hidrografía Naval, Vol. 49. Buenos Aires: Servicio de Hidrografía Naval, 1-81.

Diez, M. J., Cabreira, A. G., Madirolas, A., Martín, J., Scioscia, G., Schiavini, A., et al. (2018). Winter is cool: spatio-temporal patterns of the squat lobster Munida gregaria and the Fuegian sprat Sprattus fuegensis in a sub-Antarctic estuarine environment. Polar Biol. 41, 2591-2605. doi: 10.1007/s00300-018 $-2394-2$

Emery, W. J., and Thomson, R. E. (1998). Data analysis methods in physical oceanography. Oceanogr. Lit. Rev. 1:2.

Flores-Melo, X., Martín, J., Kerdel, L., Bourrin, F., Colloca, C. B., Menniti, C., et al. (2020). Particle dynamics in Ushuaia Bay (Tierra del Fuego)-potential effect on dissolved oxygen depletion. Water 12:324. doi: 10.3390/w12020324

Garreaud, R. D., Vuille, M., Compagnucci, R., and Marengo, J. (2009). Present-day south American climate. Palaeogeogr. Palaeoclimatol. Palaeoecol. 281, 180-195. doi: $10.1016 /$ j.palaeo.2007.10.032

Garreaud, R., Lopez, P., Minvielle, M., and Rojas, M. (2013). Large-scale control on the Patagonian climate. J. Clim. 26, 215-230. doi: 10.1175/jcli-d-12-00001.1

Garzón, J. C., Martinez, A. M., Barrera, F., Pfaff, F., Koch, B. P., Freije, R. H., et al. (2016). The Pacific-Atlantic connection: biogeochemical signals in the southern end of the Argentine shelf. J. Mar. Syst. 163, 95-101. doi: 10.1016/j.jmarsys. 2016.07.008

Giesecke, R., Höfer, J., Vallejos, T., and González, H. E. (2019). Death in southern Patagonian fjords: copepod community structure and mortality in land-and marine-terminating glacier-fjord systems. Prog. Oceanogr. 174, 162-172. doi: 10.1016/j.pocean.2018.10.011

González-Reyes, A., Aravena, J. C., Muñoz, A. A., Soto-Rogel, P., Aguilera-Betti, I., and Toledo-Guerrero, I. (2017). Variabilidad de la precipitación en la ciudad de Punta Arenas, Chile, desde principios del siglo XX. Anal. Inst. Patagonia 45, 31-44. doi: 10.4067/s0718-686x2017000100031

Guihou, K., Piola, A. R., Palma, E. D., and Chidichimo, M. P. (2020). Dynamical connections between large marine ecosystems of Austral South America based on numerical simulations. Ocean Sci. 16, 271-290. doi: 10.5194/os-16-2712020

Hamamé, M., and Antezana, T. (1999). Chlorophyll and zooplankton in microbasins along the Strait of Magellan-Beagle Channel passage. Sci. Mar. 63, 35-42. doi: 10.3989/scimar.1999.63s135

Hersbach, H., Bell, B., Berrisford, P., Hirahara, S., Horányi, A., Muñoz-Sabater, J., et al. (2020). The ERA5 global reanalysis. Q. J. R. Meteorol. Soc. 146, 1999-2049.

IOC, IHO, and BODC (2003). Centenary Edition of the GEBCO Digital Atlas", Published on CD-ROM on Behalf of the Intergovernmental Oceanographic Commission and the International Hydrographic Organization as part of the General Bathymetric Chart of the Oceans. Liverpool: British Oceanographic Data Centre.

IPCC (2014). "Climate change. synthesis report," in Contributions of Working Groups I, II and III to the Fifth Assessment Report of the Intergovernmental Panel on Climate Change, eds R. K. Pachauri and L. A. Meyer (Geneva: IPCC), 151.
Iriarte, J. L. (2018). Natural and human influences on marine processes in Patagonian Subantarctic coastal waters. Front. Mar. Sci. 5:360. doi: 10.3389/ fmars.2018.00360

Iriarte, J. L., Kusch, A., Osses, J., and Ruiz, M. (2001). Phytoplankton biomass in the sub-Antarctic area of the Straits of Magellan (53 S), Chile during spring-summer 1997/1998. Polar Biol. 24, 154-162. doi: 10.1007/s00300000 0189

Iriarte, J. L., Pantoja, S., González, H. E., Silva, G., Paves, H., Labbé, P., et al. (2013). Assessing the micro-phytoplankton response to nitrate in Comau Fjord (42 S) in Patagonia (Chile), using a microcosms approach. Environ. Monit. Assess. 185, 5055-5070. doi: 10.1007/s10661-012-2925-1

Iturraspe, R., Sottini, R., Schroeder, C., and Escobar, J. (1989). Hidrología y Variables Climáticas del Territorio de Tierra del Fuego, Vol. 7. Ushuaia: Información Básica. Contribución Científica CADIC, 201.

Joli, N., Gosselin, M., Ardyna, M., Babin, M., Onda, D. F., Tremblay, J. -É, et al. (2018). Need for focus on microbial species following ice melt and changing freshwater regimes in a Janus Arctic Gateway. Sci. Rep. 8:9405.

Kinder, T. H., and Bryden, H. L. (1990). "Aspiration of deep waters through straits," in The Physical Oceanography of Sea Straits. NATO ASI Series (Mathematical and Physical Sciences), Vol. 318, ed. L. J. Pratt (Dordrecht: Springer), doi: 10.1007/978-94-009-0677-8_14

León-Muñoz, J., Urbina, M. A., Garreaud, R., and Iriarte, J. L. (2018). Hydroclimatic conditions trigger record harmful algal bloom in western Patagonia (summer 2016). Sci. Rep. 8:1330.

Mackas, D. L., Strub, P. T., Thomas, A. C., and Montecino, V. (2006). "Eastern Ocean Boundaries Pan-regional overview," in The sea, the Global Coastal Ocean, Vol. 14A, eds A. R. Robinson and K. H. Brink (Cambridge, MA: Harvard Press Ltd.), 21-59.

Moreau, S., Mostajir, B., Almandoz, G. O., Demers, S., Hernando, M., Lemarchand, K., et al. (2014). Effects of enhanced temperature and ultraviolet B radiation on a natural plankton community of the Beagle Channel (southern Argentina): a mesocosm study. Aquat. Microb. Ecol. 72, 155-173. doi: 10.3354/ame01694

Olsen, L. M., Hernandez, K. L., Ardelan, M., Iriarte, J. L., Bizsel, K. C., and Olsen, Y. (2017). Responses in bacterial community structure to waste nutrients from aquaculture: an in situ microcosm experiment in a Chilean fjord. Aquat. Environ. Int. 9, 21-32. doi: 10.3354/aei00212

Palma, S., and Silva, N. (2004). Distribution of siphonophores, chaetognaths, euphausiids and oceanographic conditions in the fjords and channels of southern Chile. Deep Sea Res. II 51, 513-535. doi: 10.1016/j.dsr2.2004.05.001

Pantoja, S., Luis Iriarte, J., and Daneri, G. (2011). Oceanography of the Chilean Patagonia. Cont. Shelf Res. 31, 149-153. doi: 10.1016/j.csr.2010.10.013

Pérez-Santos, I., Seguel, R., Schneider, W., Linford, P., Donoso, D., Navarro, E., et al. (2019). Synoptic-scale variability of surface winds and ocean response to atmospheric forcing in the eastern austral Pacific Ocean. Ocean Sci. 15, 1247-1266. doi: 10.5194/os-15-1247-2019

Ragueneau, O., Tréguer, P., Leynaert, A., Anderson, R. F., Brzezinski, M. A., DeMaster, D. J., et al. (2000). A review of the Si cycle in the modern ocean: recent progress and missing gaps in the application of biogenic opal as a paleoproductivity proxy. Glob. Planet. Change 26,317-365. doi: 10.1016/s09218181(00)00052-7

Richlen, M. L., Zielinski, O., Holinde, L., Tillmann, U., Cembella, A., Lyu, Y., et al. (2016). Distribution of Alexandrium fundyense (Dinophyceae) cysts in Greenland and Iceland, with an emphasis on viability and growth in the Arctic. Mar. Ecol. Prog. Ser. 547, 33-46. doi: 10.3354/meps11660

Sarthou, G., Timmermans, K. R., Blain, S., and Tréguer, P. (2005). Growth physiology and fate of diatoms in the ocean: a review. J. Sea Res. 53, 25-42. doi: 10.1016/j.seares.2004.01.007

Schlitzer, R. (2020). Ocean Data View. Bremerhaven: Alfred Wegener Institute.

Seim, H. E., and Gregg, M. C. (1997). The importance of aspiration and channel curvature in producing strong vertical mixing over a sill. J. Geophys. Res. 102, 3451-3472. doi: $10.1029 / 96 j \mathrm{jc} 03415$

Sievers, H. A., and Silva, N. (2006). "4.1 Masas de agua y circulación en los canales y fiordos australes," in Avances en el Conocimiento Oceanográfico de las Aguas Interiores Chilenas, Puerto Montt a Cabo de Hornos, eds N. Silva and S. Palma (Valparaíso: Comité Oceanográfico Nacional-Pontificia Universidad Católica de Valparaíso), 53-58.

Sievers, H., Calvete, C., and Silva, N. (2002). Distribución de características físicas, masas de agua y circulación general para algunos canales australes entre el Golfo 
de Penas y el Estrecho de Magallanes (Crucero CIMAR-2 fiordos). Chile. Rev. Cien. Tec. Mar 25, 1-43.

Silva, N., and Vargas, C. A. (2014). Hypoxia in Chilean Patagonian fjords. Prog. Oceanogr. 129, 62-74. doi: 10.1016/j.pocean.2014.05.016

Silva, N., Calvete, C., and Sievers, H. (1998). Masas de agua y circulación general para algunos canales australes entre Puerto Montt y Laguna San Rafael, Chile (Crucero CIMAR-Fiordo 1). Cienc. Tecnol. Mar. 22, 17-47. doi: 10.4067/s0718686x2011000200002

Speroni, J., Dragani, W., and Mazio, C. (2003). Programa de Mediciones de Corrientes en el Canal Beagle. Informe Técnico $N^{\circ} 01$ /03. Buenos Aires: Servicio de Hidrografia Naval.

Strub, P. T. (1998). Coastal ocean circulation off western South America. Glob. Coast. Ocean Reg. Stud. Synth. 11, 273-315.

Strub, P. T., Combes, V., Shillington, F. A., and Pizarro, O. (2013). "Chapter 14-currents and processes along the Eastern Boundaries," in International Geophysics, eds G. Siedler, S. M. Griffies, J. Gould, and J. A. Church (Cambridge, MA: Academic Press), 339-384. doi: 10.1016/B978-0-12-391851-2.00014-3

Strub, P. T., James, C., Montecino, V., Rutllant, J. A., and Blanco, J. L. (2019). Ocean circulation along the southern Chile transition region $\left(38^{\circ}-46^{\circ} \mathrm{S}\right)$ : mean, seasonal and interannual variability, with a focus on 2014-2016. Prog. Oceanogr. 172, 159-198. doi: 10.1016/j.pocean.2019.01.004

Talley, L. D., Pickard, G. L., Emery, W. J., and Swift, J. H. (2011). Descriptive Physical Oceanography: an Introduction, 6th Edn. Amsterdam: Academic Press, 555.

Torres, A. I., Gil, M. N., Amín, O. A., and Esteves, J. L. (2009). Environmental characterization of a eutrophicated semi-enclosed system: nutrient budget (Encerrada Bay, Tierra del Fuego Island, Patagonia, Argentina). Water Air Soil Pollut. 204, 259-270. doi: 10.1007/s11270-009-0042-8

Torres, R., Frangopulos, M., Hamame, M., Montecino, V., Maureira, C., Pizarro, G., et al. (2011). Nitrate to silicate ratio variability and the composition of micro-phytoplankton blooms in the inner-fjord of Seno Ballena (Strait of Magellan, 54 S). Cont. Shelf Res. 31, 244-253. doi: 10.1016/j.csr.2010. 07.014

Torres, R., Silva, N., Reid, B., and Frangopulos, M. (2014). Silicic acid enrichment of subantarctic surface water from continental inputs along the Patagonian archipelago interior sea (41-56 S). Prog. Oceanogr. 129, 50-61. doi: 10.1016/ j.pocean.2014.09.008

Valdenegro, A., and Silva, N. (2003). Caracterización oceanográfica física y química de la zona de canales y fiordos australes de Chile entre el estrecho de Magallanes y cabo de Hornos (Cimar 3 Fiordos). Rev. Cien. Tec. Mar. 26, 19-60.

Valle-Levinson, A., Blanco, J., and Frangópulos, M. (2006). Hydrography and frontogenesis in a glacial fjord off the Strait of Magellan. Ocean Dyn. 56, 217-227. doi: 10.1007/s10236-005-0048-8

Vargas, C. A., Cuevas, L. A., Silva, N., González, H. E., De Pol-Holz, R., and Narváez, D. A. (2018). Influence of glacier melting and river discharges on the nutrient distribution and DIC recycling in the southern Chilean Patagonia. J. Geophys. Res. Biogeosci. 123, 256-270. doi: 10.1002/2017jg003907

Vergara-Jara, M. J., DeGrandpre, M. D., Torres, R., Beatty, C. M., Cuevas, L. A., Alarcón, E., et al. (2019). Seasonal changes in carbonate saturation state and airsea CO2 fluxes during an annual cycle in a stratified-temperate fjord (Reloncaví Fjord, Chilean Patagonia). J. Geophys. Res. Biogeosci. 124, 2851-2865. doi: $10.1029 / 2019$ jg005028

Conflict of Interest: The authors declare that the research was conducted in the absence of any commercial or financial relationships that could be construed as a potential conflict of interest.

Publisher's Note: All claims expressed in this article are solely those of the authors and do not necessarily represent those of their affiliated organizations, or those of the publisher, the editors and the reviewers. Any product that may be evaluated in this article, or claim that may be made by its manufacturer, is not guaranteed or endorsed by the publisher.

Copyright (C) 2021 Giesecke, Martín, Piñones, Höfer, Garcés-Vargas, Flores-Melo, Alarcón, Durrieu de Madron, Bourrin and González. This is an open-access article distributed under the terms of the Creative Commons Attribution License (CC BY). The use, distribution or reproduction in other forums is permitted, provided the original author(s) and the copyright owner(s) are credited and that the original publication in this journal is cited, in accordance with accepted academic practice. No use, distribution or reproduction is permitted which does not comply with these terms. 